Portland State University

PDXScholar

\title{
Lacking Legitimacy: Neoliberal Governance and the Erosion of Local Democracy in the United States and Argentina
}

Adriane Ackerman

Portland State University

Follow this and additional works at: https://pdxscholar.library.pdx.edu/honorstheses

Let us know how access to this document benefits you.

\section{Recommended Citation}

Ackerman, Adriane, "Lacking Legitimacy: Neoliberal Governance and the Erosion of Local Democracy in the United States and Argentina" (2017). University Honors Theses. Paper 441.

https://doi.org/10.15760/honors.438

This Thesis is brought to you for free and open access. It has been accepted for inclusion in University Honors Theses by an authorized administrator of PDXScholar. Please contact us if we can make this document more accessible: pdxscholar@pdx.edu. 
Lacking Legitimacy:

Neoliberal Governance and the Erosion of Local Democracy

in the United States and Argentina

By

Adriane Aileen Ackerman

An undergraduate honors thesis in partial fulfillment of the

requirements for the degree of

Bachelor of Science

in

Political Science

Thesis Advisor:

Dr. Richard A. Clucas, PhD

Portland State University

2017 


\begin{abstract}
An extension of capitalism's relentless growth, neoliberal globalization has characterized most of the policies and practices that have proliferated between nation-states since the late 1970 's, producing a "flatter" world in which spheres of influence, both economically and politically, have become inextricably interdependent. Some prominent results of this interdependence include consolidation of wealth, extreme socioeconomic stratification, greater influence of money upon politics, and deepening ideological divide within the populace. Increased sharing of the roles and responsibilities of governing with the private sector, along with increased access to information and exposure to systemic nepotism, have together undermined the sovereignty and preeminence of nation states as the most relevant governmental institutions. As nations have lost relevance and, as a result, legitimacy to their constituents, cities have picked up the slack, making great gains in effective models of interdependence via decentralization, becoming major loci for capital exchange, and increased approval ratings as "laboratories for democracy." Through a focused literature review of legitimacy, decentralization and participatory governance, as well as a comparative case study of two cities with differing political cultures, both globally-recognized for their progressive governance programs, this thesis seeks to examine the ways by which cities may effectively and sustainably cultivate increased legitimacy through participatory programming. Drawing upon emerging literature and original surveys I suggest that those participatory programs of the past have been hampered by the neoliberal, business-model approach of "governance" itself, and have not delivered the results necessary to cultivate sustained perceptions of local government legitimacy.
\end{abstract}

Key Words: Legitimacy, neoliberalism, governance, local government, participatory governance, influence and democracy 


\section{Table of Contents}

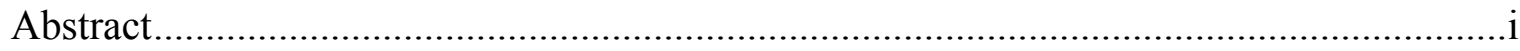

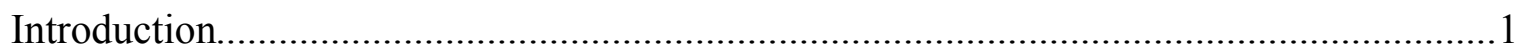

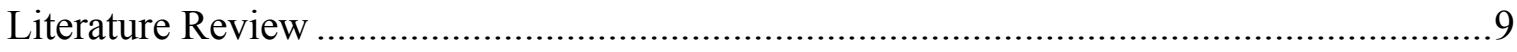

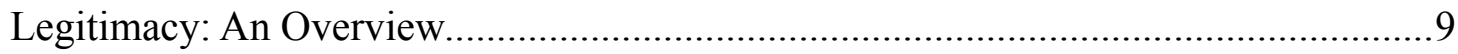

Legitimacy: Globalization, Decentralization and Governance.................................. 17

Legitimacy: The Role of Civic Engagement and Participatory Governance................29

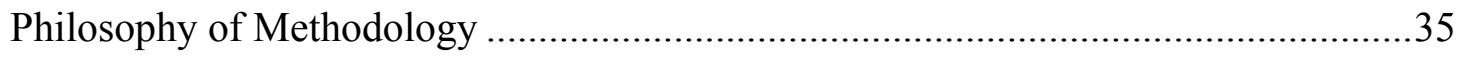

Case Study Context: National, State and Municipal Factors..........................................48

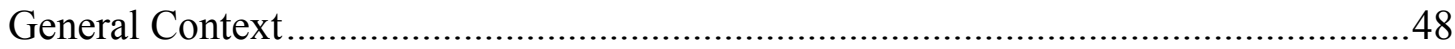

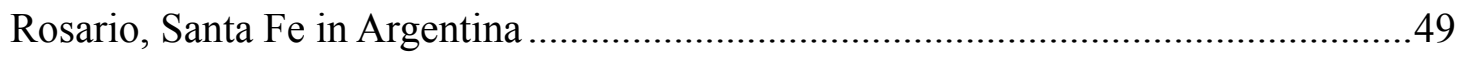

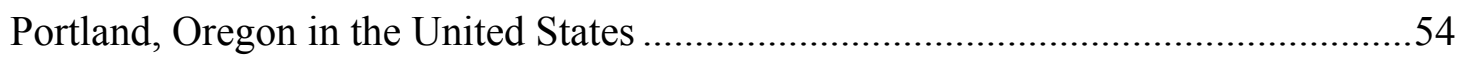

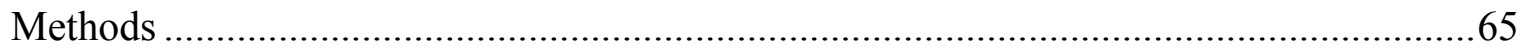

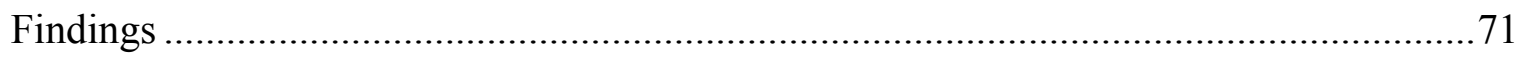

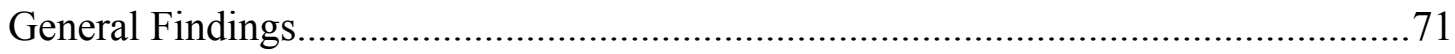

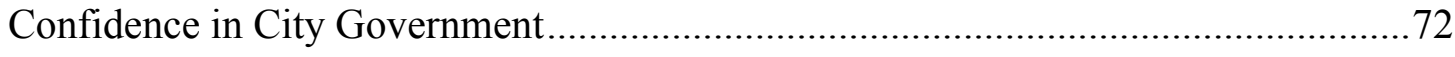

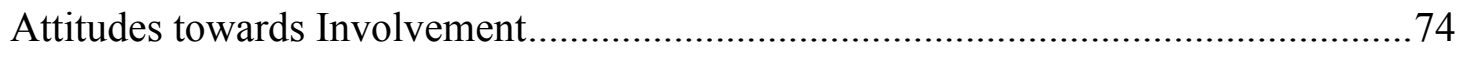

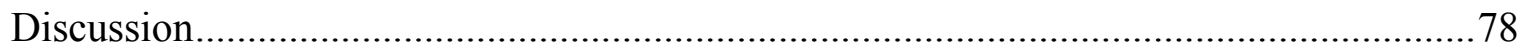

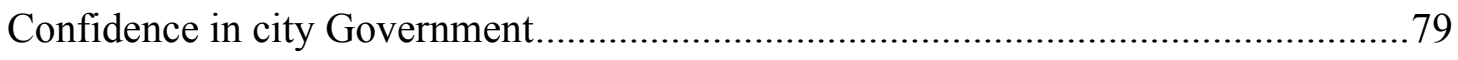

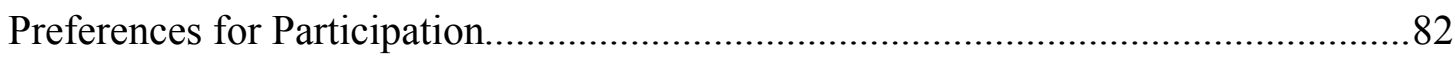

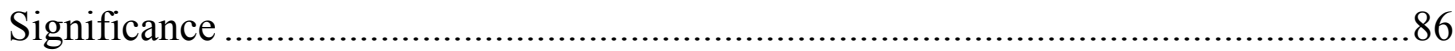

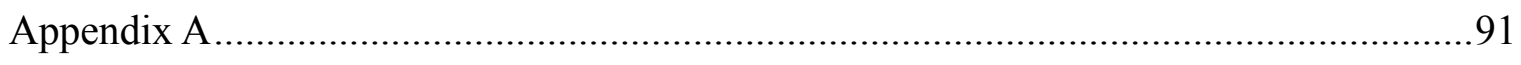

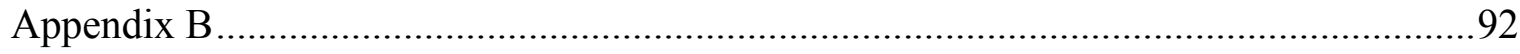

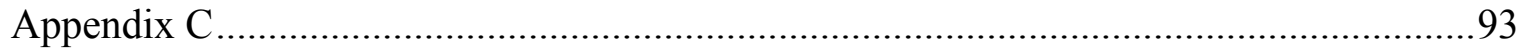

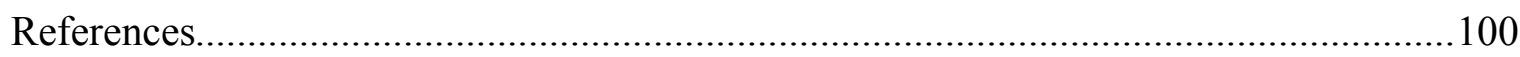




\section{INTRODUCTION}

The cultural fallout from the 2016 United States Presidential election has revealed a nation even more deeply divided than most had recognized. Rife with the greatest political, racial and socio-economic tensions that have been witnessed in generations, the populace of the United States is facing surging levels of discordance in some ways while, in others, experiencing more connectedness than ever before. Technological advances and increased information sharing between individuals, communities, governments and bureaucracies have lead to the proliferation of participatory governance and movements to increase transparency and accountability in the public sphere in novel ways (Campbell and Fuhr 2004, 3). Conversely, the consolidation of capital and increased influence of money in politics has lead to an extremely competitive political climate, in which the approval of select propertied classes is valued over the needs and consent of the masses. As the new regime seeks stability, and to assert its authority amid seemingly daily accusations of its illegitimacy, it does so in a world with a changing relationship to nation states, their sovereignty and preeminence. The U.S. federal government is far from alone in this struggle.

Decades of neoliberal globalization have resulted in a "flatter" world, one in which spheres of influence, both economically and politically, have become more interwoven and are being constantly redefined. As the world modernizes in terms of access to information and technology, perceptions of legitimacy at the national level are decreasing, especially in nations with long legacies of corruption (Gilman 2016,1). As economic inequality increases in developing and developed nations alike, public dissatisfaction with governments - even those of 
the well-established Democratic variety - is increasing, fueling public protest and rising approval of authoritarian rule along with it (Ives 2015).

Even as the relentless growth of global capitalism and neoliberalism has manifested in the further subjugation of low-wage workers, decades of deregulation and the increasingly narrow and disproportionate consolidation of wealth, the age of the internet has, at the same time, broken-up the previous monopoly on information held by academics and private news corporations, bridging divides physically as well as among the social strata. Emerging technologies that facilitate our daily lives also make it easier than ever before to navigate commerce, share information, and collaborate across the borders and barriers of a world hitherto defined by decreasingly-relevant geographies (Saunier and Ewen 2008, 173). This shift in perspective, both economically and culturally, along with waning confidence in national governments globally, has given new relevance to local-level governments, and their promise and prominence on the world stage (Saunier and Ewen 2008, 163).

As populations seek solutions to the problems created by austerity, perceived scarcity, restructuring in favor of capital, and other practices of economic globalization that have failed the labor force, a renaissance of political engagement is happening at the local level. Just as access to information has increased, so have demands for more responsive and transparent governments, and new strategies have emerged in the form of participatory governance, 
coproduction and citizen-led initiatives. ${ }^{1}$ With increased attention turned their way, local

governments are responding to the pressure to evolve in-step, and to bolster transparency,

efficiency and access by creating programs to promote civic engagement. Some of the more

innovative programs have turned to online affiliation - internet-based resources to connect

citizens with city resources and one another - as part of the "Open Government" movement.

Bypassing traditional forms of in-person affiliation and engagement, these programs seek to

socialize on the trend towards technological avenues for access to information and social

participation in the digital age. ${ }^{2}$ Other programs seek to increase residents' direct involvement in

the in-person processes of governing, like allocating discretionary funds, collaborating in

"Participatory Budgeting" efforts that seek to address the needs of the participants as well as to

train community members in the disappearing tradition of civic engagement. But are these

programs working and, if so, to what end?

1The concept of citizenship, what constitutes its merit and its use as a word to designate the otherwise inalienable
rights that are conferred upon humans at birth is problematic throughout the literature written about civic
engagement, political science, government, etc... As is discussed throughout this paper, I urge the conceptualization
of new paradigms, outside of the oppressive dominance of world capitalism - a socioeconomic ordering of the world
order that often uses the categorization of "citizen" as a means to exclude persons of lower socioeconomic status
from the provisions of citizenship that would otherwise be granted to them simply for being. With this
understanding, I find it necessary to note that a transition to a truly innovative and equitable system of governance
will necessitate, and perhaps be precipitated by, a shift in the ontological genesis of the verbiage and rhetoric that
we, in academic pursuits and everyday conversation, employ. While I do not have a suitable alternative to the word
"citizen" at this time, as I do mean to refer to constituents with the rights to fully participate in their own self
determination and that of their communities, I do defer throughout this paper to the use of the term "resident," and
the intentionality of that choice should not be misunderstood nor neglected in the total consideration of my
arguments. Further discussion of problematic verbiage that permeates the study of public policy, supports the
proliferation of institutional racism and the stratification of socioeconomic classes, can be found in the footnotes
throughout this paper.
2 In the spirit of utilizing and modeling language that reflects my normative understanding of the world and where I
would like it to grow, I seek to also negatively stigmatize the use of variations on the term "capital" when used in the
context of public planning, policy and administration. With great appreciation for the power of language, especially
institutionalized terms, I will use "socialize" instead of "capitalize" as a small action in defiance aimed towards
ultimately dismantling our global love affair with capitalism. 
The proliferation of the neoliberal business model approach to government embodied in such trends as the New Public Management wave of the 1980's caused our public affairs to become increasingly commodified and interdependent in problematic ways. Specialization, professionalization and the outsourcing of goods and services to private actors domestically and abroad has pitted local and regional governments in direct competition with capital for the public's approval of, and satisfaction with, service delivery and responsiveness (Saunier and Ewen 2008, 160; Copeland 1991, 43). By partnering with business to fund and administrate public programs, local governments undermine their own relevance and legitimacy, and put the needs of non-capital class residents in jeopardy (Kim et al 2005, 53; Saunier and Ewen 2008, 171).

In addition to lagging socioeconomic representation and diminished responsiveness, rising hate crimes, deepening political divisions and other contemporary factors that contribute to low social cohesion are relevant to those government entities concerned with maintaining legitimacy, because they have a direct relationship upon one another (Pein 2017). However, since increased civic engagement has an empirical association with increased democracy and social equity, elites from the private capitalist and public neoliberal spheres have a vested interest in restraining citizens' access to power and collective bargaining, as too much empowerment might begin to unravel the balance of socio-economic subjugation that allows capitalism to exist (Copeland 1991, 44-45). Over 15 years ago, Donna Copeland noted that, "Mean voter turnout in America is lower than any other Western Democracy," and citing the surge in politics of special interest groups and consolidated media she asserted that, "As government is increasingly 
privatized, concern for civil rights and public welfare issues diminish. Private interest replaces public interest and civic activity essential to democracy wanes" (Copeland 1991, 45-46). Therefore, civic engagement and participatory governance programs constructed from within a neoliberal context could ultimately fail at imbuing participants with meaningful decision-making powers, actual influence and, as a result, sustained satisfaction from their efforts, due to the paradigm of private interests in which they were conceived.

When opportunities to build social capital are diminished, and voter turnout takes a downward trend, legitimacy is threatened, as governments must continue making decisions with less and less citizen input. The less that decision-making powers are reflective of the interests of those most affected by the decisions being made, the less effective those decisions may become at addressing the needs of the public and the less democratic they will be (Copeland 1991, 44-45). Such a bifurcation could further diminish the populace's faith in the governing capabilities of the ruling regime - be that the local, regional or national government delegitimizing their authority. So, what is legitimacy anyway, and why should local governments be concerned with fostering it?

In political terms, legitimacy can be understood as the condition that supports our social contract with a centralized governing authority. It can also be understood as the degree to which a group of people allow themselves to be governed - by whom and under which conditions. Without the perception of legitimacy bestowed upon them by the people, governments and their ordinances would have little meaning and individuals would have little reason to comply with them. Perceptions of legitimacy can pertain to almost any type of social organization, including 
civic affiliations, religions, places of education or government (Copeland 1991). For the purposes of this thesis, I shall focus attention on legitimacy as it pertains to political institutions - namely, local and regional democratic governments.

If programs devised by municipal governments wish to maintain a monopoly on power within the government while simultaneously appeasing increased demand for citizen involvement, it is critical for governments to understand which types of citizen engagement will engender the most trust in their processes, and as a result increase the perceptions of their legitimacy as a governing entity. It is also in the best interest of the socio- and political economies of local governments to engage in programmatic efforts that most sustain those perceptions of legitimacy and that decrease singular dependence on government support for their success. Programs that call on the expertise of the populace (which is most in touch with its own needs) and non-governmental agencies (which are most responsible for providing critical services to meet those needs) alike can decentralize the concentration of power and responsibility involved in administrating such programs through co-production, without outsourcing the project to the highest private bidder. Likewise, the degree of meaningful and lasting influence that participants experience as a result of their involvement will determine the degree of the sustained success of those programs in terms of cultivating the public's evaluation of their legitimacy. As Barber states,

"If the corporation is not to defeat democracy, then democracy must defeat the corporation - which is (...) a political, not economic task. (...) Talk measures the intensity of opinion, voting does not. By adding participatory ingredients to the constitutional formula, democratic experimentation is one of reorienting rather than replacing, and (...) consent is all the more irresistible because it is legitimate" (Barber 1984, 273). 
Though both online and in person opportunities for civic engagement and participatory governance at the local level have applicable value in increasing some aspects of legitimacy, In this paper, I argue that, ultimately it is the degree to which opportunities for decision making are made meaningful through such programs, and influential power is decentralized and shared with resident participants, that will have the greatest impact on whether or not such programs garner sustained evaluations of greater legitimacy from their participants and the broader community. In their book, The Character of Democracy: How Institutions Shape Politics, Clucas and Valdini note that most scholars of legitimacy measure its presence through a combination of attitudinal and behavioral demonstrations of affirmation and consent $(2014,237)$. While many studies have been conducted to measure attitudes of approval and beliefs about government performance at the national and state level, what little has been measured at the local level is largely lacking in substantive assessment beyond basic trust in government. Usually carried out to compare with state and national sentiments, there is a gap in the studies and resultant literature around citywide attitudes specifically in localities with a prevalence of government-lead participatory programs and policies. As such, the research conducted for this thesis is intended to serve as an initial inquiry to probe the attitudinal measure of legitimacy among residents in such cities, regarding their perceptions of their own civic engagement, their level of trust in their local government to carry out its roles and responsibilities, as well as what types of participatory opportunities they believe would increase that trust more.

To that end, this paper provides historical context and some discussion around the topics of decentralization, efforts to increase participatory governance in a neoliberal context and the 
impact of those trends upon the legitimacy of those governments, as well as a discussion of the philosophical foundations of this study's methodology. A historical comparative case study of Portland, Oregon in the United States and Rosario, Santa Fe in Argentina - two cities internationally recognized for their efforts to increase civic engagement - is presented, along with the results of a survey of residents' attitudes towards their government, and their level of trust and inclination to engage therein. Chosen for their reputations of having a particularly civicallyengaged electorate, these cities represent the extreme ends of the spectrum of conditions that I would expect to result in each of the anticipated outcomes. If meaningful participation in decision-making and civic engagement can possibly result in increased levels of trust and legitimacy for local government, I would expect to find those results here, where conditions are already ripe for that style of involvement and civic awareness is embedded within the political culture.

Finally, I argue that the tensions of deepening political rifts and the legitimacy crises of democracy under capitalism cannot ultimately be solved by augmenting those practices and policies that developed institutionally under global neoliberalism, but must instead be born of citizen participation from the outset, free of corruption and profit-driven coercion. I conclude my study with several policy suggestions for building programs to increase democratic civic engagement in that fashion, as well as suggested direction for future research. 


\section{LITERATURE REVIEW}

\section{LEGITIMACY: AN OVERVIEW}

Much consideration has been given to the role that legitimacy plays in national governance since Max Weber first explicated the concept in his 1947 essay, "The Three Types of Legitimate Rule." In his book The Legitimization of Power, David Beetham built upon Weber's theories and posited that there are three "criteria for legitimate power relations," including "legality, justification and acts of consent (Beetham 1991; Roos and Lidström 2014). Since then, scholars of the social sciences have developed metrics to measure the degree of legitimacy that a government holds, and strong legitimation continues to be considered as a pre-condition to stable state authority (Gilley 2006). Taken together, these theories amount to describing the way that power is defined, earned and bestowed upon a national government and the different ways in which it coalesces or ascends the chain of consent from citizens to their governments.

Any discussion of legitimacy must highlight the concept's centrality in social and political theory (Beetham 1991). Since it deals with the conditions in which "power may be used in ways that citizens consciously accept," its discussion is of utmost import to that of political science because it, "is a major determinant of both the structure and operation of the state (Gilley 2006). As Weber put it,

In addition to the fact that they issue commands, the rulers claim that they have legitimate authority to do so, and hence they expect their commands to be obeyed. In the same way, the obedience of the ruled is guided to some extent by the idea that the rulers and their commands constitute a legitimate order of authority. (Weber 1947, 604). 
If legitimacy relates to the social contract and mutual accords that enable the power structure of the state to continue, then it is worth understanding what causes citizens to confer such approval and acceptance upon the state and its actions. While the first two of Beetham's aforementioned criteria lend themselves to a larger unit of analysis (like the nation state), cities and other sub-national governments already, in many ways, fall under the purview of the national law of the land and any dominate cultural belief systems, so the first two conditions become rather moot as we consider sub-national units. As such, the criterion that is of greatest importance when considering local governments is that of the "acts of consent," because, "in contrast to states, local government is usually closer to citizens," and that greater proximity begets a greater emphasis on subjective conditions and citizen's views (Roos and Lidström 2014). The question then becomes, how do citizens evaluate and then confer their city's legitimacy?

In The Character of Democracy: How Institutions Shape Politics, Clucas and Valdini note the challenges of operationalizing legitimacy as a concept (2015). Drawing on their own analysis, as well as the work of Beetham, Gilley, Levi, Sacks, Tyler and Weatherford, they conclude that, "Most scholars have tackled this complication by composing their measurement of two distinct elements. The first element is the beliefs of citizens (the attitudinal element) and the second is the actual behavior of citizens (the behavioral element). In other words, legitimacy should manifest as both opinion and action" (237). Perhaps the most seminal operationalization is that of Gilley's 2009 contribution of "legitimacy scores," which combine both elements by 
examining attitudes and perceptions from different wold surveys values as indicators and measures of legality, justification and consent (Gilley 2009; Clucas \& Valdini 2014).

Citizen's satisfaction with their government may be used as an indication of the degree of legitimacy that they are, or will be, willing to confer upon that government. As such, their rating of the overall governance with which they are faced or with which they interact, can be used as a measure of their satisfaction with, and potential submission to, their government. In this age of government outsourcing of services to private or non-governmental management, though, governance - especially at the local level - is not just a matter of representative democracy, but rather the cumulative provision of goods and services from a large network of "semi-independent or private providers," as well as traditional governmental “out-puts” (Roos and Lidström 2014, 138). In Governance: A Very Short Introduction, Mark Bevir differentiates "governance" from "government," "...in that it focuses less on the state and its institutions and more on social practices and activities," specifically a combination of the trends towards New Public Management (NPM) and the intersectionality of organizational governance as manifested in networks, hierarchy and markets (Bevir 2012, 13-14).

As it pertains to legitimacy at the local level, research bears out that the perception of how well all the entities that constitute general governance perform together is much more important than the actual efficacy or reach of governance efforts (Roos and Lidström 2014, 146). Adele Santana refers to those different entities that constitute governance - even the people being governed, themselves - as "stakeholders" in the equation and consideration of legitimacy (2012) and, as Ashforth and Gibbs put it, "Like beauty, [legitimacy] resides in the eyes of the 
beholder" $(1990,177)$. So, as we see, legitimacy at the local level is contemporarily defined predominately by the level of approval citizens bestow upon their local government, much more so than at the national level, wherein adherence to the law and cultural norms like voting bear equal import. Moreover, that citizen approval of the government is actually contingent upon the perception of the cumulative performance of many legitimacy stakeholders, including private and non-profit service providers.

If the bestowal of the power to govern is granted, then, by those who are to be governed, what are the factors that increase their approval of the governance in place and, in so doing, their propensity to continue to be governed by the same entity into the future? According to historical observations from Tocqueville, Putnam, Skocpol and others, the accrual of social capital through free association and civic engagement can account for higher degrees of satisfaction with government and governance among an electorate (Abercrombie, Hill, \& Turner 1986; Putnam 1996; Skocpol 1997). In the 1990's, democratic governments across the western world sought to address concerns about a "democratic deficit" by "increasing opportunities for direct public engagement in decision making," with the general understanding that such programs and opportunities would, “embed a culture of engagement and empowerment," (Johnson 2015). Through studies conducted in England, Wales, Sweden and elsewhere, the results indicate that not only have such programs of decentralization and increased engagement of citizens into the power structures and decision making processes been very successful at increasing support for existing governmental practices, but also that there is a clear distinction between the "input- and 
output-based forms of local government legitimacy," directly related to the types of policymaking with which citizens feel engaged (Johnson 2015; Roos and Lidström 2014).

In 2010 and 2011, Katarina Roos and Anders Lidström conducted an extensive survey of local policy practices in Sweden and their effects on different forms of legitimacy, how they relate to one another, and wherein they best involve and cultivate public support (2014). Crossreferencing register-based background data with survey responses from about 50,800 citizens from 111 different Swedish municipalities, Roos and Lindström were able to draw a distinction between two different types of output legitimacy: those related to welfare services and those that involve basic collective services (Roos and Lidström 2014). According to their distinctions, the former designation means those "related to nationally regulated welfare services" including schooling, social services and care for the elderly, while the former refers to any services "that need to be carried out in any community, independently of welfare arrangements (...) mainly decided locally and include streets and roads, water and sewage and cultural and recreational facilities" (Roos and Lidström 2014, 139). They also examined the effect of different levels of "input legitimacy," or the degree to which citizens perceived their involvement with the decision making processes as they pertained to policy construction and administration (Roos and Lidström 2014).

To their credit and that of their research, Roos and Lidström acknowledge that the "structural conditions" to which a locality is subject will likely shape the legitimacy of that local government (i.e. - it's constituents, their wealth, how many severe social problems may be present, etc...), meaning that the results of such a survey may be different in the United States, 
where welfare is administered differently and different social tensions arise (Roos and Lidström 2014, 137). They also call upon George and Wilding when they acknowledge that, "The relationship between policy and impact is highly complex, particularly when the purpose of a policy is to influence citizens' priorities, behaviour, norms and attitudes"3 (George and Wilding 1984; Roos and Lidström 2014). However, their evidence is strongly sorted and scrutinized. Relying on large-n analysis and multiple regression that analyzed variance in complex data sets, Roos and Lidström were able to operationalize legitimacy as the dependent variable understood to be "citizens' evaluations of the performance of the local authority on the input and output sides of the political system” (Roos and Lidström 2014, 140). Their findings indicate a strong interdependence among the different types of output policies, their administration, and the degree to which citizens believe that their involvement in the process directly effects government spending on services. Citizens seem to see the newness of candidates in office as an indicator of the health of democracy, favoring the administration of governments lead by persons who have held office for under three terms (Roos and Lidström 2014, 142).4 Though Roos and Lidström do not overtly say it, this correlation can perhaps be extrapolated as a signal to the electorate that new-comers (re: themselves and those like them) can easily obtain positions of power within their local governance, meaning that their opinions and involvement are highly impactful.

\footnotetext{
${ }^{3}$ With this simple statement, George and Wilding (perhaps unintentionally) begin to elucidate the inherent problem of policies professing to be representative, responsive, equitable or inclusive but that are created from the top-down in a neoliberal paradigm. Should the purpose of a policy be to influence citizens' priorities, behavior, norms and attitudes, or should the policy be a vehicle for those values determined by the citizens themselves?

4 This finding also reflects the theory of "relative deprivation," (discussed in further depth below) that "focuses attention on the gap between what an individual expects from life," and what is in fact able to be achieved (Little 1991, 7).
} 
Moreover, the analyses suggest that, "citizens are more critical toward welfare services in municipalities where a larger share of schools and homes for the elderly are run by private actors than in municipalities that carry out more or all of these services themselves," indicating that the public's perception of their own involvement in the administration of welfare services is of greater import than the efficacy of delivery of those services (Roos and Lidström 2014, 144). Surprisingly, both to Roos and Lidström (and perhaps to civic engagement purists with a socialist bend), one of the strongest factors in affecting public perception of good democratic governance was the amount of money spent on basic collective services. Basically, "The greater the resources that municipalities spend, the more positive citizens are in their evaluations of the services," (Roos and Lidström 2014, 144) and the amount of wealth shared collectively within a municipality directly effects citizens' positive evaluation of their local governance. This finding becomes less surprising, though, upon consideration of the decline in funding and increase in unbalanced support for social services that has developed under global capitalism, neoliberal restructuring programs and the resulting dependence on philanthropy an foreign aid to deliver social and welfare services.

That the prosperity of a city has a direct relationship with its citizens' approval of governance is not a novel notion. Money cannot buy happiness, but it sure can make things more comfortable. What is of greater import in the Sweden case findings is that, controlling for perception of involvement in budget increases for services shows that the more citizens feel that they individually and collectively had an impact on increased spending, the more likely they are to support that spending and to lend their local government greater approval and legitimacy 
(Roos and Lidström 2014, 146). More than being "mainly a reflection of structural preconditions," (as George and Wilding framed traditional understandings of legitimacy at the nation state level), Roos and Lidström conclude that the key to increasing local legitimacy lies in a combination of increased citizen involvement in the ways that policy decisions are made, correlated with a a direct increase in spending on those services which their decisions impact (George and Wilding 1984; Roos and Lidström 2014). They're not alone.

Calling on detailed individual-level data from the UK Citizenship Survey, Carolina Johnson's 2015 analysis of the effect of local civic participation upon perceptions of democratic legitimacy bears similar results. Johnson conceptualizes civic participation as the "specific type of extra-electoral, direct participation at the local level (...) the activity of individuals directly engaging in local public decision making" (Johnson 2015, 767). From her survey analysis Johnson concludes three different ways that such public participation directly increases local government legitimacy. First, Johnson finds that citizens' involvement in actual governmental processes leads to "more favorable evaluations of the fairness and inclusivity of procedures," and practices within the governmental structure (Johnson 2015, 769). Second, even if participation in the government is solicited by the government, the incorporation of non-career-politician citizens in the process ultimately subjects the process to more democratic ideas which the citizens then see reflected in governance (Johnson 2015, 767). Lastly, participation in the process begets ownership which then may "reinforce citizens' perceptions of legitimacy, particularly as regards political efficacy or the worth of a democratic system" (Johnson 2015, 767). In all three ways we see that, again, citizens' personal and collective evaluations of the overall performance of 
governance directly translates into the power that the government can derive from its appropriated legitimacy.

According to Clucas and Valdini, "The importance of legitimacy in a regime cannot be over-stated. All states, whether democratic or authoritarian, must cultivate it," and, "in terms of state survival, performance, and even quality, more legitimacy equals better democracy" (2014, 236). Again as Weber explains and Clucas and Valdini are apt to note, "if citizens believe in the moral validity of the government's rule, then coercion is not necessary," however, this understanding should not be conflated with the idea that citizens must like governmental policies or political actors in order to imbue them with their consent and, thereby, legitimacy $(2015,235)$. As we will learn below, though, even if efficiency of services is negatively affected by increased participation, or if individual politicians or bureaucracies do not receive high approval, citizens are more likely to offer consent and evaluations of legitimacy to a government if they see themselves and their opinions reflected in its processes. Therefore, well-cultivated legitimacy can help governments more aptly weather the storms of unpopular political sentiment, divisive political conditions and policies without incurring great instability (Clucas and Valdini 2014, 236).

LEGITIMACY: GLOBALIZATION, DECENTRALIZATION AND GOVERNANCE

A "quiet revolution" of decentralization has been taking place over the last thirty years in local and regional governments throughout the world (Campbell and Fuhr 2004, 4). Perhaps unbeknownst to the general public in all of its particulars and technical jargon, this overhaul of 
municipal identity has far-reaching effects that have transformed, and continue to change the political landscape of cities, and the world, with great rapidity. Beginning as a response to the anti-democratic ramifications of neoliberal globalization, the proliferation of political professionalization and the rising importance of cities as independent hubs of capital production and distribution, decentralization has served as a mechanism to increase representation, democracy and legitimacy within local governance in the forms of public participation, nongovernmental collaboration, transparency and accountability. This nongovernmental collaboration has been economically viable and popularized under the term "governance" to a degree that has rendered its relationships almost inextricably-interdependent. Not all assessments of "governance" and its associated programs are positive, though. Some, like Andrew Ives, believe that the word has been brought into prevalence and high use on purpose, to, "impose a free market model on the very act of governing" (Ives 2015). To begin the discussion of why and how this municipal renaissance has come to be and why some could believe its origins be so nefarious, requires that we establish a brief understanding of capitalism and neoliberal globalization.

As considered throughout this paper, capitalism refers to the socioeconomic model that ascended to dominant-paradigm-status in the post WWII redistribution of world power, resulting in the existing world order by which we find our global systems defined today (McMahon 2012). Via the subjugation and exploitation of a global, stratified class system, prosperous nations began to consolidate and multiply their wealth in international markets, and a global leadership in terms of development emerged. With the United States at the helm, the global development efforts that 
served as boons to international profiteers also occurred in tandem with the intentional proliferation of American-style democracy. Soon, many nations began to develop economically in step with U.S. wishes and, with them, so did the global exchange of information and capital, begetting the proliferation of homogenous approaches to bureaucratic organization and the beginnings of the professionalization of politics. From the advent of the Westphalia treaties to the late twentieth century, "cities, as political units, became irrelevant (...) nationalized, mere components of nation states, cogs in national economies" (Saunier and Ewen 2008, 7). As nations sought to claim their positions in the New World Order, cities got lost in the shuffle, as did the value and relevance of their governing structures. "White Flight" to the suburbs in the United States, fueled by the post-war economic boons of the 1950's, literally left the residents in cities to languish in the wake of economic development elsewhere, further stratified by race, socioeconomic status, and political ideology (Digby-Junger 2000).

Part of the economic boon that the United States and other developed and developing nations experienced between the end of World War II and the mid-1960's, was due to the resurgence of the welfare state and the popularity of Keynesian-style economics (Ives 2015). Keynesian liberalism was predicated upon intervention in regards to protecting a social safety net, including public education, Social Security, affordable and accessible healthcare, and provisions for public works and the arts. While still capitalistic in nature and, therefore, dependent upon the exploitation of a working class, this economic approach sought also to protect access to upward mobility for certain sectors of the working class. Its efforts to do so are why it was labeled as "liberal" and began to be overwhelmingly associated with more left- 
leaning politics (Ives 2015). As global capital began to accrue and the wealth of nations grew, the consolidation of power began to permeate the public sphere in increasingly noticeable ways.

In the race to build wealth that ramped up in the 1970's, the world took a sharp turn from Keynesian-style intervention, and began to codify economic practices that favored the profit of corporations over populist protections. Under the leadership of Margaret Thatcher in the United Kingdom and Ronald Reagan in the United States, nations and global economic associations began to deregulate everything from international trade practices, tariffs and restrictions to the ways that federal governments funded social service and welfare programs domestically. ${ }^{5}$ The breakdown of the social safety net allowed income inequality, abject poverty, crime and authoritarian governments to thrive, like that of the most recent military junta in Argentina, which exerted its strength, bolstered by the ruling capital class until 1983, when it was overthrown by working class mobilization (Karush, 2002). This global greed and deference to market versus moral-driven public practices resulted in the default and near economic collapse of many nations and international institutions began to be increasingly forced to rely on the funding and leadership from major economic world players (re: the United States) to lead the way forward into a new global, economic interdependence. Their solutions to those problems, as derived from the dominant paradigm of capitalism and commodification, make up the playbook of neoliberal globalization as we know it today. In Public Capitalism: The Political Authority of Corporate Executives, McMahon states,

\footnotetext{
${ }^{5}$ While I associate neoliberal deregulation here with Reagan, it is important to note that, in actuality, the programs and fiscal measures that eventually led to more robust neoliberalism under his administration began with the Carter administration before him. While the association is so colloquially robust that the term "Reaganomics" has become synonymous with many neoliberal platforms, Carter began the trend by deregulating airlines, banking, natural gas, railroads, and trucking industries (Lind, 2011).
} 
"We have been exploring ways in which respect for the requirements of private morality could conflict with the implicit morality of the market, which is to say, with the achievement of economic efficiency through profit-seeking in a competitive environment. We should be clear about the force of this point. There is no inherent conflict between the profit motive and the requirements of private morality. Profit could be sought within the boundary set by the requirements. What gives rise to conflict is that crossing the boundary is necessary for the efficient operation of a capitalist system. The actions required for efficient operation are specified by the implicit morality of the market, and this code conflicts in some respects with private morality" $(2012,127)$.

While a complete argument for, or against, capitalism is too massive of an undertaking for this thesis, an understanding of the global costs of deregulation, profit-driven policies and neoliberal globalization is necessary to understand the abrupt shift in practices that directly followed this era of massive de-democratization. Globalization is, of course, a phenomenon as old as trade and, perhaps, civilization itself, but neoliberal globalization herein refers to those intentional efforts on behalf of the profiteers of the global capitalist system to consolidate wealth and power in an ever-more concentrated fashion, be that in public or private practice, as delineated above. As it pertains to our discussion of the United States, neoliberal practices manifested in fortified, hierarchical management-style governing techniques, like the "New Public Administration" wave of the 1980's, which sought to replicate standard business practices within the standard operations of local, state and national government. It is from this trend wherein defunded governments were forced to rely on private intervention to deliver services to constituents - that business terms like "stakeholders" began to be applied to the actors involved in government problem-solving, and "governance" emerged as concept to cement the union between the private and public spheres (Ivers 2015, Copeland 1991). In the context of our international discussions, neoliberal globalization can be understood as referring to those 
measures of economic restructuring through massive loans and aid packages, U.S.-backed coups to entrench capital-friendly power in otherwise democratizing states, and pervasive cultural colonization that have resulted in high levels of corruption and instability in extremely vulnerable nations, like Argentina, one of the subjects of our case study.

In their 2002 assessment, Rebuilding Effective Government: Local-level Initiatives in Transition, the United Nations Development Programme blames the,"Unfortunate combinations of conflict, ineffective state-building, economic crisis, misguided neoliberal ideology, and fiscal stringency," for the systemic roll-backs of otherwise-hallmark provisions of advanced market economies $(2002,7)$. "Significant (at times massive) reductions in expenditures for such essential activities as health, education, and programs to aid ethnic minorities have often resulted" (Rebuilding Effective Government 2002, 2). With this understanding of the proliferation of neoliberalism, our attention may turn to the concurrent trend of decentralization.

The problem of increased consolidation and hierarchy within government is particular to democratic regimes - both developing and established - as each force, when unmitigated, plays upon the other to erode democracy. Increased market forces can limit the value placed upon nonprofitable and less efficient means of involving more residents in democratic processes and, if programs or services are deemed non-essential to an increasingly consolidated elite, they are less likely to receive equal funding or attention. The homogenizing and destabilizing effects of neoliberal globalization were not all detrimental to the cause of democracy, however, as their impetus in the for-profit paradigm encouraged governments to begin to assess their own efficiency and to look outward for solutions. At the same time, the destabilizing and deleterious 
effects of some aspects of globalization agitated civically-engaged individuals and organizations to seek out more horizontal and innovative practices to bolster the meaningful democracy that they were missing. Two different approaches to the same dilemmas created by global socioeconomic stratification and the revolving crises of capitalism began to develop: one of business-style governance, the other of communitarian-inspired participation, or direct democracy.

With the advent of increased telecommunication capacity, the internet and global information sharing occurring to an unprecedented degree, the 1990's saw an abrupt end to business as usual in economic, political and social practices. Explaining the shift as a product of global instability and collective yearning for greater democracy, Bernstein and Coleman reflect that:

The two great motivators of political life, fear and hope, rise to the surface in such times. A desire and demand for autonomy underlies both. Fears of disorder, insecurity, loss of control, and domination motivate the drive to legitimate power and order precisely to protect autonomy. At the same time, hope may spur individuals and groups dissatisfied with the old political order to take advantage of such changes to push for more control over their destinies, resist domination or oppression, promote social justice and pursue the good life. These efforts reflect the hope that autonomy may be enhanced as authority is reconfigured. (...) In short, in creating the openings for such renegotiations and questions, globalization rapidly expands the scope of questioning of legitimacy. The challenge, then, is how to promote security and order while, at a minimum, preserving autonomy or, more ambitiously, creating opportunities for those seeking new forms of enhanced autonomy" (Bernstein 2009, 4).

Simultaneously, those professionalized political actors tasked with increasing the efficiency of government practices began to realize that, "the hierarchical, top-down style of management in traditional bureaucracies restricts the involvement of employees in their own jobs," and that, 
without a means to a sense of ownership in the process, state employees were alienated from their organization, with experiences of reduced commitment and, therefore, reduced quality of output" (Peters 2001, 47-48). Governments began to realize that, "hierarchy imposes enforcement costs on government that voluntary contracting would not" (Peters 2001, 48).

The seeds of decentralization were sown in the 1980's, when the collapse of the Soviet Union, the Velvet Revolution in Czechoslovakia and the political resistance in China's Tienamen Square highlighted the global tensions of centralized authorities and their eroding legitimacy (Campbell and Fuhr 2004, 12). Out of the chaos sprang a new approach that built upon the New Public Management style that had been cultivated, but in a way that was intended to promote responsive, legitimating governance. Facilitated by emerging telecommunication technologies, transnational networks were able to be developed with ease for the first time in history. Networks of bureaucrats, elected officials, activists, organizers, and others were able to spontaneously form, share best practices in development and test them out alongside one another. Spain and Latin America lead the way in the initial phases of these public administration trends (Saunier and Ewen 2008).

With its rich history of participatory, direct democracy dating back to the successful anarchist communes of Catalonia in the 1930's, Spain emerged as an early progenitor of the best practices of "good governance" (Ives 2015; Saunier and Ewen 2008).

“Transnational networks enjoyed a renewed importance from the late 1980's. Under predominantly democratic regimes, Latin American countries shifted from state- and nation-centered models of development and political relations to more open ones, in which international influences were allowed to filter. Simultaneously, decentralization increased the autonomy of municipalities in various aspects of urban policy, which subsequently became involved in international relations, or what has been termed 
'paradiplomacy' - that is, the diplomacy of subnational governments." (Saunier and Ewen 2008, 153).

Planners in Barcelona began to implement methods of "coproduction," to solve public problems with the collaboration of many "stakeholders" and "actors," including the private and non-profit sectors. With the advent of transnational conferences like the 1993 World Social Forum in Rio de Janeiro, practices from Barcelona were shared with officials from Brazil, Argentina and elsewhere, and the best practices gleaned there began to be implemented in the South American region.

In "Leadership and Innovation," Tim Campbell and Harald Fuhr discuss the "quiet revolution" of decentralization that began in Latin America in some places well before the 80's, and later throughout much of Latin America by the 90's $(2004,4)$. They note that the change was so "rapid" and "wholesale" that it created a "new model of governance characterized by fresh leadership, widespread participation, and a new willingness to mobilize revenues" (Campbell and Fuhr 2004, 11). They also discuss the limitations that precipitated the decentralization namely the macroeconomic system that was rigged in favor of central governments at the expense of the budgets and political autonomy of subnational units.

"Organizational inefficiency and low institutional performance in many local governments were part of the justification that sustained state-directed development. Weak local governments fit logically into a 'traditional' system of financing municipal development and making corresponding arrangements between officials in local governments and those in the larger public sector" (Campbell and Fuhr 2004, 11).

The authors note how this behavior was just one part of a cycle that resulted in decision makers at all levels of government engaging, "in bargaining processes and populist and clientelestic rent allocation to acquire and maintain political support." (p11). 
Before the trend of decentralization efforts caught on globally, locally elected officials in Argentina as well as in the United States, "relied on the strength of centralized parties to support and advance their initiatives and personal careers" (Campbell and Fuhr 2004, 12). As governments in Latin American were decentralizing due to the influence from their former colonizers in Spain, the re-democratization of nations that had been held under authoritarian repression and transnational neoliberalism, the United States was a little slower to take up the trend of decentralization, and the public responded to similar frustrations in different ways. The 1990's saw a rise in the popularity of term limits in the United States, and the better part of that decade was characterized by political upheaval and unprecedented turnover of elected officials in office. As the decade went on and the upheaval settled, young, newly-elected political outsiders finally brought the internationally flourishing trends of decentralization to their states and cities. Business interests from Wall Street to Main Street, already clued in to the merger of interests that "governance" was granting the private sector in Spain, Latin America and elsewhere, adopted strategic planning, "as the idiom for municipalities to find their way in this transitional economic and political process between a Fordist and post-Fordist economy," and the continued "transfer of "best practices" internationally began to serve as a "conduit for the sale of private services in consultation, urban engineering, and architectural design" (Saunier and Ewen 2008, 170-171). In their work exploring the transnational municipal movement, Saunier and Ewen reflect that,

"Logically, the relationship between public and private actors was central to urban interventions: private firms gained a leading role in municipal administration, taking advantage of the business opportunities offered by the urban renewal process and steering the political transformation jointly with the mayor and city council. That 
conjunction facilitated Barcelona's integration into international capitalist circuits. Its authorities claimed that they succeeded in combining free-market economics with social welfare and political legitimacy, through a three-tier system of governance that made it possible for politicians, business, and the local community to map out the city's future" $(2008,160)$.

While this assessment is of Barcelona's strategy specifically, the three-tier system of governance became applicable universally, as programs for decentralization and increased interdependence between governmental and private actors began to proliferate throughout the world.

Globalization in the neoliberal context has also been recognized as "heralding a historic rupture in city-state relations, shifting from a state-centric to a city-centered configuration of socioeconomic, political, and geographical power," (Saunier and Ewen 2008, p173). Structural reforms of the 1990's, privatization and lower tax barriers influenced the "devolution of policies and legal responsibilities from the national and provincial governments to municipalities, which redesigned government and governance in the process" (Saunier and Ewen 2008, 157). As states strove to become smaller and more efficient, the emerging models and practices were recognized as fitting perfectly within the local level. Globalization, "compressed the space-time continuum, removing cities from their territorial straightjackets and allowing them to effectively inhabit the spaces "in between" conventional national borders, through which they steer the flows of capital and information that together constitute the neoliberal capitalist economy" (Saunier and Ewen 2008, 173).

As decentralization continued to bolster the position of cities within world governance and markets, capital investments began to seek haven in more and more cities for production and participation in governance practices. This drove cities to compete with one another to offer 
more attractive advantages like lowered or forgiven taxes with little-to-no additional resources to shape their initial competition.

"To fulfill the new tasks that decentralization, privatization, democratization, and liberalization placed on their shoulders, municipalities had to rely on constrained resources. Their limited economic revenue, which relied on a meager fiscal base, particularly when urban economies underwent major crises, were a limiting factor. Other elements such as geographical location; the relationship between municipal, regional, and national governments; local educational standards; and wealth accumulation also differed from cities in Europe or North America. Political and social leaders, as well as economic actors, had to be highly creative to elaborate policies and agreements that would enable them to take advantage of scarce and quite volatile opportunities" (Saunier and Ewen 2008, 157).

The legitimization of local governments and participatory practices became increasingly prominent in terms of their recognition by international and domestic institutions alike. For example, the proliferation of professional associations of city managers and governing officials, like the National League of Cities, the International Municipal Lawyers Association, and the International City/County Management Association (which celebrated its centennial in 2014) to name just a few. In addition to associations, international institutions have recognized the rising role of cities by way of conferences, studies and compacts, including the International Council for Local Environmental Initiatives, the United Nations' Agenda 21 (including its subsequent 3 versions), the Council of Europe's Charter of Local Self-Government, the 6th Annual Global Forum on Reinventing Government held in 2005 and that resulted in the Seoul Declaration on Participatory and Transparent Governance, and 2017's International Conference on the City hosted by the International Academic Forum (Kim 2005, vii). 
If democratic governments should prioritize cultivating legitimacy as a means to shore up stability and public compliance, it follows that, when possible, those efforts should ensure that that cultivated appraisal of said legitimacy, and the consent that constitutes it, are as robust and sustainable as possible. As is argued above and reiterated throughout, increased involvement of citizens in the determination of the policies and programs that most effect them has a direct correlation to their resulting increased satisfaction with, and approval of, their governments. As John Burke argues, "Greater responsibility to democracy may be the cure for democracy's own ills (...) stronger consent binds citizens to the state, officeholders to office, and he calls upon democracy to affirm that bond by giving individuals opportunities for participation" (Copeland 1991, 44 - 45). Guy Peters adds that, "This is clearly an age in which government finds it difficult to legitimate its actions without active public involvement" $(1996,47)$. Studies also show that, when certain parameters of efficacy are included in the experience, the act of civic engagement usually results in more, sustained engagement (Pancer 2015).

In his book, The Psychology of Citizenship and Civic Engagement, Pancer (2015) lists the quantifiable impacts of civic engagement, including: more appropriate, accessible, and better utilized services; more effective organizations; more representative, inclusive, and accountable organizations; greater access to resources; increased sense of community and increased prominence of community leadership; greater safety and security as well as reduction in crime; greater individual and aggregate-level health and well-being; increased wealth via greater 
educational achievement; (and most importantly to our discussion) better evaluations of government efficiency and legitimacy.

When considered from the lens of governments seeking stability, it is safe to conclude that by increasing citizens' influence within their own determination, local governments can increase the governability of those citizens, their "support and obedience" (Beetham and Lord 1998, 9). What, then, is civic engagement, and what constitutes that involvement and participation that governments should seek to bolster?

According to Ehrlich "civic engagement," is comprised of individual activities oriented toward making,

"a difference in the civic life of. . . communities and developing the combination of knowledge, skills, values and motivation to make that difference. It means promoting the quality of life in a community, through both political and nonpolitical processes" (2000, p. vi).

For the purposes of this discussion, civic engagement will be considered more narrowly, precisely as it relates to political processes and the effect of involvement on the individual participant. Furthermore, civic engagement is both distinct from, and equatable to, participatory governance in a variety of contexts, but in the context of this paper, the term "civic engagement" will be used interchangeably with "participatory government" or "participatory program" in that it is assumed that if participation in a government program is occurring, it falls within the purview of civic engagement. It is worth noting, though, that this understanding has not always been the case and is a construct of new developments in decentralized government and contemporary governance, as is discussed in the preceding section. 
In his 1996 review of emerging models of governing, Guy Peters writes, "In its simplest form participatory government is plebiscitarian, with the public being asked to decide all manner of policy issues by a direct vote," but he is sure to clarify that in order to be deemed participatory, those decisions must go beyond the more traditional confines of those "yes" or "no" choices made by citizens participating in a referenda, with an agenda set for them by political elites (Peters 2001, 54). As noted above, the proliferation of decentralization resulted in two different approaches to increasing civic engagement. The first can be considered as communitarian in nature, focused on the meaningful involvement of residents in conducting the affairs that most affect them - in other words, participatory. Participatory democracy can include, "such mechanisms for citizen feedback as school boards, neighborhood policing, and urban planning, to name but a few" (Gilman, 2016, 7). The second can be understood as "governance" in the neoliberal context that we have hitherto discussed: profit-driven, business-modeled, pragmatically approached for highest efficiency and most often striving to offer the illusion of involvement without actually sharing decision-making power.

While programs of governance can be labeled participatory, the difference lies in the normative understanding of the programmatic goals, the paradigm in which the program may be construed, and interests that ultimately govern its funding and administration. As governments, activists, advocates and private actors have learned to practice new forms of governance and craft new opportunities for civic engagement in the neoliberal era, many programs have purported communitarian intention while, in practice, falling squarely under the purview of governance. Programs to increase civic engagement can therefore be understood as falling within 
a spectrum between discursive and deliberative - or those that consult participants versus those that meaningfully involve them in the decision-making process, giving their participation commiserate influence with other actors involved in the process. To that end, though, civic engagement and participatory programs can - thanks to technological innovations - run the gamut from online to in-person; group participation or individual.

Whatever its form, when provided within certain positive parameters, civic engagement can have far-reaching effects for individuals, their communities and society at large. As Mark Pancer notes in The Psychology of Citizenship and Civic Engagement, “...people who are civically engaged tend to be better adjusted, socially and emotionally," than their non-engaged counterparts $(2015,9)$. It is difficult to determine whether or not civic engagement is a causal mechanism of emotional adjustment, due to the correlational nature of the variables at play, but Pancer cites "several experimental studies that indicate civic engagement is indeed a causal factor in this relationship" $(2015,9)$.

Moreover, as a means to cultivate sustained evaluations of legitimacy, it is pertinent to note that the effects of civic participation last decades, if not lifetimes. Research conducted in a variety of fashions - looking at participation in protests, service-learning and school-based engagement, or in political organizing - show that participation in any one of these endeavors leads to greater occurrences of participation throughout participants' lives compared to other individuals who were not involved in such activities (Pancer 2015; Beane and colleagues 1981; McAdam 1988,1989; Jennings 2002). The effects of involvement are not universal, however, and the conditions of primary involvement tend to determine whether or not continued civic 
engagement will be sustained (Pancer 2015, 18). Traditional opportunities for civic engagement, especially those of participatory government practices, require substantial time and effort on the part of participants, and aren't always accompanied with commiserate support from governing entities. In addition to barriers to access, Pancer refers to a 2011 survey conducted by Pamela Attree and her colleagues in which the evaluation of the "subjective experience of community engagement" found some reports of "consultation fatigue" and participants being "overwhelmed by the amount of work they were expected to do" (Attree et al 2011, 252; Pancer 2015, 24).

Not all civic engagement is created equally, nor will each type of engagement yield the same results. Taylor and Pancer identify "high-quality civic activities" as those that will yield the aforementioned benefits with consistency at the individual and systemic level (2007). They identify "high-quality civic activities" as those, "that are supported by family and friends, occur in organizations that recognize and appreciate those who are involved, and provide opportunities to develop skills, discover new interests, form relationship, and do things that matter and are enjoyable," and note that such activities should result in sustained involvement and ongoing benefit (Pancer 2015, 153; Taylor and Pancer 2007). Many critiques of participatory government and civic engagement programs have to do with their lack of outreach to, and support for, participants of all means, educational levels and employment statuses to engage easily. Rachel Swaner's recent study of the effects of participatory budgeting (PB; one of the most popular forms of new participatory government) on government legitimacy found that, "PB has the potential to have an impact on them [participants] in multiple ways: feeling more engaged with and connected to their community; developing leadership skills; and having 
stronger relationships with government," (Swaner 2017, 96). She also found significant problems with conventional approaches to $\mathrm{PB}$, including high attrition levels due to time commitments needed and discouragement over projects not actually coming to fruition, as well as a feeling of tokenization within the process, both of participants themselves and - in many land use project terms - of the idea of their communities" (Swaner 2017). In fact, Swaner points out that the nebulous idea of "community" is another term (like "stakeholder") that has been effectively coopted by private interest to vaguely imbue feelings of connectedness and social cohesion within projects that often do not materially provide such results (Swaner 2017). These sort of approaches to programmatic development belie a neoliberal paradigm and value system that places the potential profit of securing contracts over actually increasing the experience of democracy and ownership of process for participants.

Another significant finding from Swaner's study is that, while participants in programs like participatory budgeting experience increased evaluations of trust, approval and legitimacy for specific local leaders and elected officials as their exposure to them and their bureaus increases with participation in the civic engagement programs, they do not necessarily lead to increased evaluations of legitimacy for the government as a whole (Swaner 2017, 99-101). This finding is especially important as programs like participatory budgeting come of age in the global sphere and can finally be reflected upon with decades of hindsight - the 20/20 of which may reveal that they are not, in fact, increasing legitimacy with the scale and scope that might have previously been assumed. 


\section{PHILOSOPHY OF METHODOLOGY}

For this study I've employed a variation upon a traditional Multi Method Research (MMR) approach. While my MMR approach does consist of multiple methods (case study, comparative case study and small-n statistical analysis), it does not seek to explicitly identify the causal mechanism or its corollary explanation that is normally associated with the empirical approaches, like the data analysis I present. Rather, I seek plurality and deviance within my research in a metaphysical sense that hopefully echoes the nature and ontology from which I implore readers of this thesis to consider the aggregate effects of the socioeconomic and philosophical paradigms from which we consider problems of governing in our modern age of unfettered growth and late-stage capitalism. In begging the question(s) of how global capitalism and neoliberal policies effect government, governance and the relationship between individuals, their communities and their power to self-determination, I would be remiss if I did not also consider my own normative biases in reaction to that same paradigm and, in doing so, attempt to conceptualize and practice theories and praxes that, too, originate outside of those norms. Taken together, the plurality of my methodology aims to paint a comprehensive picture of the cumulative consequences of neoliberal deregulation upon attitudes of democracy, participation and governing, rather than to focus on an individual-level explanation or one particular policy.

The New Introduction to Daniel Little's Varieties of Social Explanation and Martin Hollis' chapter, "Philosophy of Social Science," in The Blackwell Companion to Philosophy are wonderfully complementary pieces to begin unpacking the layers of philosophy and meta-theory 
that together comprise the elusive answers, if any truly exist, to the epistemological and ontological questions that frame the study of Social Science. In them, Hollis and Little seek to ask and answer the questions that are, in Hollis' words, "what general kinds or categories of phenomena there are in the social world, what sort of method is best able to reveal how it works and what warrants claims to knowledge of these matters" (Hollis 2002, p2). In describing the utility of the application of philosophy to the social sciences, Little quickly introduces the idea that the two disciplines are already inextricably entwined, and makes a case for why social scientists should continue to increase their reflection upon - and valuation of - qualitative observation and interpretive narrative-building, in addition to gathering empirical, quantitate data. By first offering a definition of scientific knowledge and then touting the achievements of the natural sciences (eg. the ability to make generalizations, highly accurate predictions and to construct reliable technology) Little sets the stage for the argument in favor of an integrated approach to the study of social science - one that compensates for the highly irregular and unpredictable nature of social phenomena by integrating "corrigibility and anti-foundationalism" whilst maintaining "a coherentist epistemology and a perspective of causal realism" (1991, 2-3). In effect, Little argues in favor of MMR.

Little ends his piece by drawing several significant conclusions regarding the science of social phenomena. One conclusion is that those regularities which can be observed empirically are contextually contingent, observed and interpreted with social bias and should be regarded as “"phenomenal' rather than 'governing"” (Little 1991, 15). Another conclusion is that, since "higher-level social entities (...) must be understood as being composed of individuals in 
interaction," so should social science "avoid the error of reification," so common to structural explanations that seek to reduce institutions to "some kind of abiding permanence independent of the individuals who constitute them" (Little 1991, 16). Finally, though, Little reaffirms the value of empirical explanation by asserting that "The discovery of social causal mechanisms is the foundation of social explanation," due in large part to the key role Positivist and naturalist rigor and data proffer to the credibility "in almost all convincing social explanations" (1991, 16-17). In this study I refer to evaluations of local level legitimacy as a cumulative causal mechanism that points to the significance of understanding the aggregate systems of neoliberal governance structures as the root of explanans of the concepts and questions herein.

As mentioned above, Hollis's "Philosophy of Social Science," covers similar ground to Little's work while also adding several dimensions to the discussion, including a visual heuristic of "The four keys to analysing social action," which serves as a matrix-style guide to the different approaches to, and understanding of, the social sciences from both ends of the ontological and epistemological spectrums $(2002,2)$. The matrix delineates the distinction between explanatory epistemological approaches, and those rooted in interpretive understanding, the discussion of which becomes central to the ensuing sections of the chapter, which also explore how those different epistemological approaches interact with ontological underpinnings that rely on systems theories and rational choice theories, alike.

Considering which methodology carries most utility and value requires reflection upon the type of question being asked or answer being sought, which in turn begs the question(s) of meaning and nature that Hollis invites us to consider. First focusing on the explanatory end of the 
spectrum, Hollis calls on naturalists, Structuralists and empiricists such as Hobbes, Hume, Mill and Marx, and their arguments in favor of deterministic forces, or "some kind of social or psychological physics," that govern the natural world $(2002,4)$. The argument therein does not question the supremacy of empirically-based knowledge acquisition, but rather the ontological focus between the individual actor as the causal agent or the aggregation of the individual - those social groups or institutions that act as agents unto their own - as the unit of analyses to answer the questions of "what is?" (Hollis 2002, 4-5). The aim of this quest to identify the best process is ultimately that of answering questions of whether or not there can be found degrees of probability or predictability when assessing the social world and, if so, how best to go about that. Stepping into the Post-empiricist realm, Hollis explains that any assertion, in either direction, is inherently biased, informed by, “...an active interpreter bringing theories to bear. Hence there are no facts that are neutral between all interpretations and, in explaining anything, we are choosing which theory to prefer" (Hollis 2002, 6). To this end I intend to wear my bias openly in my assessments - namely that neoliberalism and, more explicitly capitalism, is immoral and detrimental to processes of democracy.

What drives the preferential choice in which theory to adopt? Hollis puts forth several explanations that inform the answer(s), including social individualism, perceived morality, rational choice theory and, specifically, its application within the context of game theory. Any discussion of choice, though, is framed firstly from the understanding that the rules of the game must be established prior to the moves that are made within it, and that different actions (or moves) carry different meanings, at the individual, public and objective levels. To add further 
complication, it follows that to understand meaningful motivation we must understand, again, the biases inherent to subjective interpretation, including our assessment of our own social world, from within which we are asking these questions in the first place.

In an attempt to delineate this line of thinking clearly, Hollis enters into a discussion of roles shaped by societal expectations which can be at once normative and fluid, constantly redefined by, and recast in the light of, both individual and group action. These actions, as Hollis lays out, can be instrumental, calculated and based on practicality/perceived outcomes, or they can be expressive, wherein so much value is assigned to the goal of the action that the consequences do not factor into the resulting move. Again the theme of the inherent, stunting limitations of relying on any one theory or approach emerges as Hollis reflects that, "What makes rational choice theory (or decision theory) complex is not the complexity of human psychology but the problems of dealing with risk and uncertainty" $(2002,14)$. Here we recognize Little's argument in favor of combining analytical forces breaching through Hollis' assessment as he states, "In relating explanation to understanding, we are trying to make sense of a single world" $(2002,17)$. On the one hand the argument continues that, since "all systems of thought rely on 'paradigms' which govern what counts as reasonable," empirical explanation cannot fulfill all the utility that it seeks to (Hollis 2002, 16). Whereas on the other hand, even if action can be identified as stemming from within the qualitative social context in which it exists, it can also be "explained from without," since natural laws apply to humans just as they do to worms, following the example given by some naturalists (Hollis 2002, 16). Ultimately, Hollis again implores the consideration of the, "original Enlightenment hope" that saw the advancement of 
the social sciences bringing about "moral and political progress," societally, as well as a new iteration of the underlying original question of "whether truth, happiness and virtue are indeed bound together by an indissoluble chain" $(2002,19)$.

The study of causal analysis and explanation as it pertains to social phenomena hinges upon the ability to identify where the most pertinent work of causal mechanisms occurs within the structures and superstructures that lead to, influence or bring about the formation of the phenomena itself. During the analysis of any phenomena, it should be possible to identify many potential contributing factors to the phenomena's occurrence and, from them, extrapolate various working theories as to the phenomena's inception or potentially similar, future extrapolations.

In chapter 5 of Varieties of Social Explanation Little builds upon his previous exploration of causal analysis by first considering Functional explanations and Structural explanations - two different approaches that both "deal with human agency," but also suggest that the significance of causality may lie at the aggregate level as opposed to ultimately at the individual $(1991,112)$. While Little explores two different types of Structural exploration - causal and non-causal - we shall concern ourselves exclusively with the causal variety, which posits that "societies are complex systems that embody an indefinite range of social structures," and that many notable features of society may be explained "as the causal consequence of the particular details of these structures " $(1991,103)$. Considering a strict definition of what constitutes a social structure provides a useful container from which to evaluate its utility. Little lays out three conditions that must be satisfied in order for something to be considered a social structure, including (1) its persistence over time; whether or not it is instantiated (a feature that contributes to its relevance 
to a given society), (2) the significance or importance of its properties - specifically those that can be considered as "independent" and separate from those individuals that "occupy roles within the structure," and (3) that it imposes "constraints on the actions of persons involved in it" (1991, 103).

Little refers to social structures as, "enduring regulative systems that define opportunities and constraints that guide, limit, and inspire individual action," (1991, 104). By limiting the scope of individual decision making - either with a proverbial carrot or stick - the significance of the structure and its work as a causal mechanism can render the microfoundational explanation less relevant, depending on the structure and situation being considered. In this sense it is the social structures themselves that, by incentivizing or penalizing different types of individual actions, are able to exert their influence on social processes and, thereby, "serve as standing causal conditions within social explanations," (Little 1991, 104). The work, then, in the sense we are considering it, is constituted at the aggregate level of the social structure that carries its own singular significance - irreducible to the sum of its parts or the individual agents that enact work at the component-level. As such, Structural explanations can best be applied to organizational outcomes, like those of bureaucracies - the work of which might still be recognized even in the absence of the individuals that constitute its workforce, or to certain social norms as they pertain to specific social features in the sense that without the social structure of the norm itself, the resulting feature would never occur.

Materialism is one framework from which to consider capitalism. The theoretical framework suggests that societies tend to be ordered around the technology through which they 
provide their population with the means and material to meet their most basic needs, as defined not only biologically, but by their shared social ideology (1991, 114-119). In it, Marx asserts that there is a mechanism of exploitation inherent to predatory economic systems like capitalism as, in order to function in perpetuity, such an economic order depends on the subjugation of an entire sect of the population, namely those lower classes of labor that exist in a class-stratified society, bifurcated along lines of material wealth. Marx explains the impetus for individual, rational actors to engage in their respective roles within such a society to maintain stratified and disproportionate ease of access to material goods in two different ways. On the one hand, those who benefit the most from the exploitative structure are incentivized to perpetuate it in order to protect their interests and may exert influence over social institutions in an effort to cultivate a particular type of social order. What kind of social order would benefit the upper echelons of a stratified, class society? One that idealizes and rewards subservience via a multifaceted ideology that is meant to prevent exploited classes from being able to recognize their own subjugation.

Jon Elster, though, in his article, "Marxism, Functionalism, and Game Theory: The Case for Methodological Individualism," thought that Marx's treatment of causal mechanisms was left wanting (1982). Specifically, Elster argues that Marx's understanding of capitalism - its superstructure and the causes that its effects bring about - were much too functional in nature as explanation. Much like Little in his exploration of Methodological Individualism, Elster argues for the need for more individual storytelling to fruitfully connect the dots within the theory. He asserts that Marx's understanding of the collective actions of the capitalist class to provide the conditions for the perpetuation of capitalism relies upon an extrapolation of purposiveness that is 
spurious: it does not account for the individual motivations of the rational actor and thereby fails to tell a convincing story (Elster 1982, 458-461). Without a convincing narrative of the microfoundational causal mechanism, Elster argues that Marx's "Long-term functionalism," falls prey to the usual defects - it becomes arbitrary, ambiguous and inconsistent $(1982,459)$. Or as Little puts it in Chapter 9, "A putative explanation couched in terms of high-level social factors whose underlying individual-level mechanisms are entirely unknown is no explanation at all," $(1991,196)$. To the extent with which I agree with this understanding, future research done on this thesis topic should include personal narratives constructed from interviews of respondents who consider themselves civically engaged and hold low levels of trust in their local governments.

Elster does not entirely reject the notion of functional explanation in all of its applications though, just as Little does not deny the importance of microfoundational understanding when pursuing an aggregate-level explanation. For both authors, the intentional, thoughtful application of the most appropriate ontological approach differs along with the phenomena to be explored. Elster does insist, however, that in the context of a historical materialist exploration of capitalism, such as Marx's treatment of western capitalism, the individual underpinnings that constitute the way that game theory may be applied are of greater import than the aggregate-level explanations that may be more seductive as well as more problematic when a theorist's aim is to explain within a predetermined context, rather than to understand a phenomena objectively; empirically. Ultimately, Elster supports the ideological aims that frame the understanding with which Marx approaches the formation of his explanation, he simply seeks to forge "better links 
between aggregate analysis and the study of individual behavior," and, in doing so, makes another argument for the thoughtful synthesis of methodological approaches, as they pertain in this instance to economic and game theories $(1982,477)$.

In his 1985 effort to explain exactly "Why the Philosophy of Social Sciences is So Hard," Brian Fay begins by posing several controversial questions, not the least of which deals with unpacking just how to understand the relationship between theory and metatheory in the Social Sciences today (150). In doing so he contends that the discipline's long-held aspiration of forming a well-articulated "a priori" metatheory to "clearly and unequivocally provide the firm foundation on which to build a theoretically solvent account of human life," belies a "fundamental misunderstanding" of that relationship between theory and metatheory (Fay 1985, 150). Just like Ahmed \& Sil do in terms of methodology, Fay critiques the Social Science community for attempting to construe its theory, "in order to self-consciously employ a particular metatheory," in an attempt to overcompensate for its, "lack of success relative to the natural sciences" but, in doing so, failing to also thoroughly examine "the foundations of their enterprise," $(1985,151-153)$. He logically asserts that a methodology employed by Social Scientists within a particular philosophy cannot then prove the essential correctness of that philosophy, given that their actions are taken in a particular way because of that philosophy's particular framework (Fay1985, 151).

However, this does not preclude Fay from acknowledging how understandable it is for anyone - including Social Scientists - to ground their own metatheoretical positions in accordance with their metaphysical beliefs $(1985,154)$. Moreover, "what is distinctive about the 
philosophy of social science today is that these metaphysical beliefs are themselves part of what is in dispute in arguments regarding the worth of a particular metatheory" (Fay 1985, 154). In fact, Fay offers that

there are good reasons why metatheoretical disputes about the social sciences are so explosive and intractable: they involve different answers to the most basic question of the subject, namely, what is the nature of social science; they involve at their center metaphysical principles of a very high order of abstraction; and they raise ideological considerations of very great intensity. $(1985,157)$

Previous reflections referenced within this section have focused on which level of abstraction the work of social science - a particular question or phenomena - is being done, but here Fay is able to draw on that aforementioned understanding and ask what should the work of Social Science, itself, be? To answer that question, Fay first discusses three dominant models of Social Science and their respective aims.

According to Fay, the Interpretive Model seeks to "reveal structures of meaning," while the Naturalists seek to "provide causal laws," and the Critical Model wishes to "uncover latent content which has socially disruptive power" $(1985,154)$. Since each of these aims is grounded in foundational beliefs about the world and how it works, these different metaphysical approaches preclude the emergence of a unifying metatheory. As an example, Fay illustrates a few of the many different approaches to possibly take when explaining schizophrenia. On the one hand its explanation could be rooted in an Interpretive Model, in which a person's, "perceptions of their situation, their beliefs about it, their desires with respect to it - in short, the 
meaning of the situation," explain the onset of the schizophrenic episodes $(1985,162)$. This explanation, however, eschews the Naturalist approach not just in terms of regarding schizophrenia as something different than a disease or biological function, but even more so by employing a vernacular that is entirely inapplicable within an analytic science. Again, the chasm between the ontologies is too wide and deep to bridge at the best-practices level of abstraction.

With this consideration, Fay puts forth another controversial idea, namely that if "there is no relatively self-consistent structure whose underlying principles" can be uncovered and elucidated, then the kind of "descriptive philosophy" found in the mainstream philosophy of natural science, to which the discipline has thus far aspired, mustn't be the true aim of the Philosophy of Social Sciences $(1985,164)$. As Fay puts it :

that the long-standing assumption (and dream) of the philosophy of social science as found in the analytic tradition - that the analysis of concepts is the way to settle the questions of what understanding human life really involves - must be abandoned. (1985, 164)

In its place, Fay suggests that the Philosophy of Social Sciences must instead be an "essentially revisionary enterprise," (1985, 164).

By acknowledging that metaphysical predisposition inherently translates a particular understanding of the social world into an equally particular political position, Fay suggests that scholars within the Social Sciences can free themselves of the aim of being philosophically descriptive and politically objective $(1985,164)$. By embracing their own philosophical biases and acknowledging one another's metaphysical and theoretical paradigms, Social Scientists may 
further hone what can be deemed as successful research within their field, and can work to effect change within their discipline and the world. Finally, Fay diplomatically suggests a program of true rationality that may enable emerging scholars to work better together, especially in the coming destabilizing political times, encouraging "both an attitude of aggressive willingness to propose new models as guides for social inquiry, and an attitude of humble willingness to allow that others may well be right and that one's own radical program is wrong" (Fay 1985, 164). It is with this understanding that I offer my unabashed critiques of capitalism and the biases from which they stem as the paradigmatic and nomothetic lenses from which I approach the research herein. 


\section{CASE STUDY CONTEXT: NATIONAL, STATE AND MUNICIPAL FACTORS}

\section{GENERAL CONTEXT}

For this comparative case study, two cities were chosen for both their distinct political and cultural similarities and their differences. Rosario and Portland both enjoy international reputations as cities that intentionally designed and supported systems for increasing civic engagement before the influx of neoliberal deregulation and less-than-populist leadership ultimately defunded or rendered useless the strongest components of those programs. Both cities have strong legacies of neighborhood-based organizing, popular movements for equity and justice, bucking more conservative national norms of political culture, they have similar geographies, economies and a shared focus upon intentional, sustainable development. At the time that this study was performed and attitudes in both cities were being collected, they were each experiencing the last few weeks of majorly-contested national, regional and local elections with similar economic considerations and major candidate characters.

Their differences in terms of political institutions provide enough contrast to measure for the attitudes of respondents across those differences, allowing my expectations and arguments ample challenges against which to be tested. For each city I explore the economic, political, physical and cultural attributes that uniquely define them. I also outline the particular programs and policies that were employed to bolster civic engagement. Following this section I delve into the methods that I employed within each study as well as a discussion of my findings and their significance. 
ROSARIO, SANTA FE IN ARGENTINA

\section{Economic Climate}

Argentina's history is punctuated by severe and sudden economic transition, political upheaval and a legacy of volatile instability. With experiences like the excessively violent, repressive rule of the last military junta and the crippling economic crises of 2001 still fresh within the collective memory, Argentinians consistently consider economic instability and political corruption as two of the most important issues facing their nation (World Values 228J 2014, Emerging 2014). It's long history of dependence on foreign aid and its current political economy based on years of ballooning debt and inflation provide a rich case study for our investigation.

Since being "integrated into the world economy after 1500" Argentina, much like the rest of Latin America, has been beholden to foreign investment and Import Substitution Industrialization that has created an economic climate of dependency, resulting in the economic health of the nation being tied to the global economy in an especially vulnerable and volatile way (Vanden 2014, 157, 165-167). Though Argentina was once hailed by its European colonizers as an investment rich with "comparative advantage" (Vanden 2014, 156), and despite an unprecedented (albeit elite-concentrated) economic boom a century ago, increasing foreign debt especially in the form of structural adjustment and neoliberal expansion - has relegated Argentina to the realm of inconsequential world economic players, and has caused the instability that so characterizes Argentina today. To say that Argentina's economic history has had the quality of a pendulum is and understatement. As one Economist article puts it, 
"Argentines reach for the metaphor of the "pendulum" to describe the swings of the past three decades: from loose economic policies in the 1980s to Washington-consensus liberalisation in the 1990s and back again under the presidency of Néstor Kirchner and now his widow, Cristina Fernández de Kirchner. But the image of a pendulum does not do justice to the whiplashing of the economy (...) the repeated recessions of the 1970s and 1980s, the hyperinflation of 1989-90, the economic crisis of 2001 and now the possibility of another crisis to come. Argentina is a long way from the turmoil of 2001 but today's mix of rising prices, wage pressures and the mistrust of the peso have nasty echoes of the past" (The Tragedy 2014).

In fact, Argentina has defaulted eight times in its history, four of which have occurred in the past 40 years, with the most recent happening in 2014 and 2001 (The Tragedy 2014).

The default of 2001 was by far the most impactful and clearly illustrates the linkage between economic instability and political foul-play. After years of denying the predictions of economic collapse from international observers, the Argentine government found itself at the precipice of extreme default and crises. In order to prevent total collapse, the ministry of the economy announced harsh measures that severely restricted the purchasing power of Argentinians, including the amount of money that they could withdraw from their banks or travel with. In an overnight response, Argentine cities erupted into food riots, which soon gave way to wide-scale protest and the turn-over of two executive administrations within just two weeks (Pérez-Liñan 2002). Many argue that the Argentine economy has yet to recover and that the severe fluctuation of the peso and the remaining restrictions on personal bank account withdrawals are evidence of its legacy of instability. Coupled with a legacy of clientelism and political patronage that is just as pervasive as its economic instability, Argentina has done little to foster a sense of security for its populace in the time since that last great crises. Economic practices that emphasize short term gains, concede to foreign investors and elite interests and 
generally leave political actors unaccountable to their populace continue to abound and contribute to a climate of anxiety and distrust of authority in day-to-day life for most Argentinians.

When the citizenry of developed and developing nations are forced to subsist day-to-day without physical or financial security, the effect is akin to devolving an otherwise advanced society to pre-industrial conditions. The development of, and emphasis upon, democracy will be forsaken in favor of the survival needs of the individual (namely stability), and corruption will abound, leading to future economic decisions that favor the short-term gain and contribute to mounting economic instability.

\section{Political Climate}

In its national context, Rosario is a city within a larger system of federalism, in a nation known for its strong history of deep party divides and political corruption. Argentina's closed-list proportional representation electoral system mandates that parties assign candidate list order at elections and, in doing so, incentivizes party allegiance, if not party discipline. The legacy of Spanish colonization and subsequent economic models of international dependence have left Argentina subject to variable international market performance and generations of mounting debt. While the country has a strong tradition of populist mobilization, sentiment and party ideology, it was during its greatest period of socialization under the rule of Juan Peron that Argentina first began to see its nascent democracy riddled with patronage and clientelism as a means to pacify elites and attempt to evade growing economic instability. Decades of economic instability and citizen discontent created the perfect conditions for a revolving door of military 
take-overs and attempts at re-democratization that lasted for the majority of the 20th century. Following the last, and most brutal, military junta that ended in 1983, democracy returned to Argentina and, with it, the particular electoral systems, political parties and their elite networks, that continued to foster clientelism and political corruption. Following the nation's largest economic crises in 2001, Argentinians were left in a state of severe instability and economic inequality everywhere, including in Rosario.

\section{City Attributes}

At over 1.35 million inhabitants, Rosario is Argentina's third largest city and is recognized as one of its most prosperous municipalities. Nestled on the border of the Paraná River, Rosario benefits from the wealth of surrounding agrarian production in the province of Santa Fe, sharing many similarities with Portland, Oregon, both geographically and economically. Although the city (municipal) government exercises a high degree of autonomy over its own functions - such as setting various taxes, signing contracts and administering its assets - these depend on federal financial allocations to the provincial level, which the provincial government in turn distributes to municipalities. This sort of distribution of wealth is inherent to federalism, but is especially problematic in the context of Argentina's unabashedly clientelistic party system. Since the federal government has been ruled for over a decade by the Peronist Kirchner administrations, the Santa Fe and Rosarian governments have experienced de facto sanctioning as a result of their Socialist Party affiliation. In effect, federal funds are withheld from social programs within the province and city due to their political ideals, which diverge legally from that of the federal government. 


\section{Legacy of Civic Engagement}

The Rosario city government includes an executive branch headed by the Mayor and a legislative branch that consists of 22 directly elected counselors, or consejos. Secretaries head different divisions of the city, representing such sectors as Education, Health, Labor and so on. There is a government branch and secretary for Civic Engagement and it is from this sector most of Rosario's existing civic-engagement programs began in 2002, during a concerted municipal effort to increase public programs and citizen participation. In 2004, Rosario was awarded the UN-HABITAT International Award for Best Practices in urban development, based on these efforts (Urban 2014). Included amongst those programs is Rosario's most famous - a participatory budget called "Presupuesto Participativo" - the first of its kind in Argentina. The program elicits volunteer participation from city residents in all six of Rosario's distinct neighborhoods, which were, themselves, created in direct accordance with the Barcelona model set forth in the 1980's and shared through transnational networks. Rosario dedicates a significant amount of its annual discretionary budget to the efforts of Presupuesto Participativo, as explained by former Mayor, Miguel Lifschitz:

"Participatory budgeting was initiated through various pilot initiatives at the neighbourhood level, which sought to test out different methodologies. Then, during the economic crisis in 2001, participatory budgeting was scaled up, based on the model from Porto Alegre.(22) Thereafter it has progressively been revised and adapted to the specific social context of Rosario. Participatory budgeting has now been through six annual cycles. At present, around 35 million Argentinian pesos (approximately US\$ 11 million) are allocated to each cycle. This is not a significant proportion of the total municipal budget (about 5 per cent) but this is because most of the budget is spent on fixed costs; however, it is a significant part - nearly 30 per cent - of the discretionary budget, that is, the money that is available for the city government to allocate to other projects" (Almansi 2009, 27). 
While it has been lauded with such awards, the programs for which it was initially acclaimed have begun to be systematically defunded in recent years, leading to widespread unemployment and rampant inflation - cycles that Rosarians, and Argentineans in general, are accustomed to. The programs which once supported neighborhood self-direction and established centers for access to services in each of the six barrios of the city have fallen entirely on the city to fund, as opposed to previous years wherein neoliberalisation had extended a network of interdependence to the city in the form of federal and private partnership. With the funding rug pulled from beneath their feet, programs like participatory budgeting in Rosario have become largely rhetorical efforts to bolster the optics of the city, rather than the material conditions of its residents. Dissatisfaction with the programs and the government itself is growing and the "widespread deterioration of infrastructure and services and economic hardship have turn these local governments into implementers of social policy," has Rosario in the unpleasant position of having to provide more of a safety-net with less resources to do so (Reilly 1995, 45-51).

PortLAND, OREGON IN THE UNITED STATES

\section{Economic Climate}

While the experience of severe economic upheaval and repressive military regimes does not punctuate the history of the United States to quite the same degree as it does in Argentina, the political climate, and current relevance of local government, within the United States can be traced to moments of national instability and transition, both economically and politically. For 
instance, until the Great Depression of the 1930's, American federalism was defined by influential and disparate state governments that managed much of domestic affairs, however disjointedly, while a national government with limited scope at home took charge internationally. During that major economic crisis, however, state governments were unable to sufficiently provide for their inhabitants, and as they turned towards the federal government for support, they bolstered its relevance with dramatic reforms and legitimized its power by conferring upon it the responsibility of increased service management and delivery (Clucas 2006). As power continued to consolidate in the federal government, states became increasingly irrelevant, and "by the 1960s some political commentators began to ask whether the states were even needed" (Clucas 2006, 2).

In a slow response to their increasing inconsequentiality, states began to enact reforms in the early 1960's that, when combined with other pivotal moments in the development of modern U.S. politics such as the Voting Rights Act of 1965 and a general resurgence of citizen activism, began to turn the tides in favor of state relevance. As previously discussed, neoliberalism took flight in the 1970's and, under Reagan's administration in the 1980's, the neoliberal deregulation of the market and labor safeguards accelerated in conjunction with the emergence of "a New Federalism [which] shifted considerable responsibility for governing to the states" (Hedge 1998, 1). Regan's New Federalism was characterized by, "devolution, deregulation and 'defunding,"” that gave the states greater control over their policies and development, and that "forced the states to do more with less" (Hedge 1998, 2). By providing funding to states in the form of block grants with broad mandates, federal lawmakers eschewed the strict spending and programmatic 
parameters of the Keynsian/New Deal past in favor of the states' rights to do with the funding as they pleased (Ives 2015). Intended to be more efficient and cost effective than federal administration, this new laissez faire freedom to spend threw regulatory oversight out with the bathwater and opened the door for a redistribution of funds and services that tended to favor communities with political influence over those with actual, material needs. At the same time, a sustained period of professionalization brought greater bureaucracy to bear in the state legislatures, as well as the judicial and executive branches.

As state administrations increased their purview, they also began to more greatly share responsibilities and service delivery with local and regional government entities. And as the role of states became more robust and complex, so too did their funding sources. When block grants became insufficient to address the growing needs of their populations, states began to increase property and income taxes and as markets experienced increased deregulation and neoliberalization, a culture of professionalization imbued changing state governments with more business-like models, inviting private insight and interests into the development and funding mix.

State and local governments have always been the closest entities to the public and in the context of the United States in the 1980's and 1990's, their increased capacity induced the public's demand for equally-increased responsiveness. In an attempt to bolster public favor and private gains, proponents of neoliberalism in public office furthered the agenda of deregulation and devolution by slashing taxes and adjusting budgets to reduce spending and the prevalence of the welfare state, which was becoming increasingly viewed as archaic and inefficient (Hedge, 
1998; Clucas, 2006). During the same time, legislative upheaval and the further commodification of the societal sphere led to more partisan and volatile local elections and greater competition between states and special interests. Thomas Dye described a framework in his "model of competitive federalism [sic]" from which the emerging type of federalism could be, "viewed as a marketplace where states compete with one another for residents and firms by offering the most attractive package of taxes and services" (Clucas, 2006, p8). While such reforms increased public involvement by popularizing initiatives and referenda, they also created conditions in which term limits and the demand for reelection opened the door for corruption, special interest influence, legislative fragmentation, gridlock and the magnification of, "the role and importance of money in state politics, producing new ethical challenges and threatening the quality of representation and the ability of state governments to make difficult policy choices" (Hedge 1998, 5; Clucas 2006).

Since the era of Regan's New Federalism began, the U.S. has experienced several economic crises, including the savings and loans scandals and oil scarcities of the late 1980's, the dot-com bubble burst of 2000-2001 and, most recently and most devastatingly, the Great Recession of 2008-2010. Due to the hegemony that the United States holds over the global economy, each of these crises had far-reaching implications the world over. Domestically, though, they cumulatively contributed to the even more rapid devolution and deregulation that began under Regan, characterizes neoliberalization, and has continued through today. In attempts to offset the destabilizing effects of these crises, the U.S. government repeatedly bailed out banks and corporations while slashing budgets for public works and continuing to deregulate markets 
in order to clear any obstruction for capital. As these practices continued to grow, so did the gap of economic inequality as well as that between the parties and along ideological divides. Over the decades, as neoliberal economic practices changed both the material realities and lesstangible social fabric of the United States, local activists and community leaders responded to the commodification of their rights and services with calls for greater participation, democracy and decentralization of the increasingly-consolidating powers-that-be.

\section{Political Climate}

The rich history of civic engagement, social capital and the valuation of decentralized government that the United States boasts is well documented and deeply entrenched within the national identity. The oft-cited observations of Alexis de Tocqueville's tour of the U.S. in the 1830's and his subsequent ethnographic treatise on the utility of civic associations as a means to prevent government consolidation praised the propensity of United States residents to perpetually form voluntary associations and engage civically with one another in a myriad of ways (Skocpol 1997). Almost equally as famous are the observations made by Robert Putnam over 150 years later, that the once-prolific tendency to form such associations and to generate social capital that had defined the American spirit and experience were, as of 1993, rapidly disappearing (Putnam 1996). With them, he argued, the fabric of democracy in the United States was unraveling. While extraordinarily important to democracy, such civic associations are not the only factor that has contributed to the unique construction of democracy in the United States. Other provisions - like the initiative and referenda processes referenced in the previous section - 
have also shaped the character and caliber of democracy in the U.S. and, pertinent to the case study herein, originated in Oregon.

The ballot initiative movement came about in the United States during the Progressive Era - those decades on either end of the turn of the twentieth century that brought into being so many of the reforms and codified policies that define the spirit of civic engagement in the United States. While the Progressive Spirit was alive and well in the West, it was most embodied in the 1902 decision in which an overwhelming number of Oregon voters approved a "legislatively referred ballot measure" which "enabled Oregon citizens to directly initiate amendments to the Oregon state constitution, as well as enact new state statutes" (). It also enabled the right of referendum, which allowed Oregon citizens to overturn statutes or laws passed by the Oregon legislature. This system (commonly referred to as the Oregon System), became popular throughout the United States, and conferred upon the electorate the ability to take initiatives from the ground up, legitimating their involvement in the process of their own governing, and cementing the political culture that would later provide for Portland's world-renowned programs for civic engagement.

\section{City Attributes}

Like Rosario and just as its name suggests, Portland is a port city, though it is situated on the confluence of two rivers, as opposed to Rosario's one. Initially prized for its utility as a center of shipping, production and fabrication Portland has developed a robust reputation as a destination city for tourism, sustainably-minded businesses, tech start ups, artists and liberals - 
another commonality it holds with Rosario. As of 2015, Portland proper had 632,309 residents, but the greater Portland-Metro region, which encompasses seven counties, was estimated at $2,389,228$ residents. One of the nation's most sought after cities, between 2014 and 2015 an estimated 111 people moved to the Portland-Metro region per day - "a growth rate of $1.72 \%$ " with 400,000 new residents expected to make their way to the city itself by 2035 (Beebe 2017). Beyond the affordability it boasted before its popularity soared, one of the reasons the city became so attractive to so many is its unique Urban Growth Boundary, which protects urban growth into agricultural area, and keeps natural, scenic getaways very nearby. This particular city attribute is managed by the Metro Council - the only regional government in the United States with popularly elected officials (Cassie 2010).

Portland's city council is the last remaining commission form of government among large cities in the U.S., with the Mayor, four commissioners and a City Auditor comprising the council (City Government). City Commissioners, along with the Mayor, also administrate and oversee individual bureaus as assigned by the Mayor and also act "in a quasi-judicial capacity" concerning "land-use and other types of appeals" (City Government). Just like Rosario, Portland has also received its fair share of awards and recognitions, including "Most Livable City in America (Money Magazine), Best Place to Live (CNN), Number 1 Cycling City in North America (Bicycling Magazine), among the Top 25 Arts Destinations (AmericanStyle magazine), and the Most Child-Friendly City in Americall (Irazabel 2005, 146 as cited in Cassie 2010, 4). While the aforementioned regional government (Metro) and the Urban Growth Boundary distinguish the Portland Metro area in terms of planning and governance innovations, it is the 
Office of Neighborhood Involvement (originally the Office of Neighborhood Associations) that put Portland local government on the map.

\section{Legacy of Civic Engagement}

Between the mid-1950's and 60's a trend emerged across the nation in which city planners, in observation of the "white flight" from urban areas to the suburbs, began to view "blighted" urban areas as irreparably damaged and in need of demolition in order to be renewed (Leistner 2013). Portland was no exception to this trending rule and, having not been previously accustomed to involving "community members in their planning activities," developers engaged in a series of projects in the name of "urban renewal," that sought to demolish thousands of homes within the inner-Portland area, to make way for highways, freeways and homogenized areas of commerce (Leistner 2013, 186-187). Having recently witnessed Urban Renewal efforts gone awry in other parts of the city, community activists began to publicly organize against government land use and to "advocate for revitalization, rather than replacement, of their neighborhoods" (Leistner 2013, 81).

Several conditions converged at once to bolster the efforts of the community organizers, including federal provisions for increased citizen participation in federally-funded programs, "the emergence of active and often angry neighborhood association organizations [that] made local residents the actors rather than the objects in neighborhood decisions," as well as a changing of the guard to a new, younger cohort of elected city officials between 1967 and 1970 (Leistner 2013, 82). Most notable among those elected at the time was Mayor Neil Goldschmidt, 
who helped to create Portland's innovative neighborhood association system which, led by activists with city support, rendered a "presence that politicians and planning administrators could not ignore," (Abbott 1987, 192).

With the help of recommendations provided by a City Council-established District Planning Organization (DPO) Taskforce, city leaders responded to resident demands for further involvement in city planning affairs in 1974 by establishing a new Office of Neighborhood Associations (ONA), with full time staff and increasing avenues through which resident voices could be heard (Leistner 2013, 82). Between 1974 and 1979 the number of active neighborhood associations doubled from 30 to 60 and today they number at 96 (Abbot 1987t, 200-201). Along with increased organization and place-based representation, the ONA and DPO Taskforce also helped to establish Budget Advisory Committees (BACs) to provide resident oversight to each of the many different city bureaus and agencies (Berry et al 64; Leistner 2013). Though BACs did not provide the type of instrumental participation in budget allocation that Rosarians may experience with Participatory Budgeting, they were a way for "citizens to become directly involved in the nitty-gritty of city policymaking," (Leistner 2013, 113).

These local-level efforts did not occur in a vacuum. They were, instead, best-case outcomes of federal initiatives from the 1960's and 70's to combat urban blight and to embrace more participatory governance. Through the Community Action program of the Office of Economic Opportunity, the Model Cities program, and the Housing and Community Development program, the federal government incentivized such local and state-facilitated initiatives as Portland's development of the Office of Neighborhood Associations (Leistner, 
p908-909). Also in association with those efforts, Portland organizers worked with the City Council to create the "Neighborhood Needs" process, through which neighborhood associations were more directly connected with project developers that could help them assess and address their community's most pressing needs, as well as planning provisions that ensured " 30 days notice of city decisions that affected their communities" (Leistner, 913).

The results of this civic experiment were immediately and overwhelmingly positive. Not only were neighborhood organizers successful in defeating the proposed freeways and staving off the demolition of thousands of houses in inner-southeast Portland, but the thriving system of dual power that was established with the neighborhood association system became a beacon of best practices in decentralization for the rest of the nation. In the late 1980's a Tufts University research team compared 5 U.S. cities known for their efforts to increase civic engagement and to utilize federal funds to provide access points to participatory governance (Berry et al 1993, 113; Leistner 2013, 913-914). Portland stood out among the cities studied due to the training it provided to new members of the BACs and the high level of participation that Neighborhood Associations enacted within the city planning processes (Berry et al, p113). Even Robert Putnam himself, in a study conducted during the same time as the Tufts study above, "identified Portland as one city in which community involvement was increasing, while it was declining in nearly all other U.S. cities" (Putnam and Feldstein 2003; Leistner 2013, 2).

Sadly, during the 1990's and 2000s, Portland's civic engagement began to go the way of national and global neoliberal trends: it devolved, got defunded and deregulated. With newly approved property tax limitations, funding for the programs stagnated, more professional and 
contemporarily-trained officials were elected to local office, and as the city's population increased, many of the most-lauded programmatic elements ceased to be (Leistner 2013, 2). Specifically, the BACs, the Neighborhood Needs Process and provisions for neighborhood planning were all eliminated from the ONI budget. As the number of immigrants and refugees ballooned in Portland and the socioeconomic strata of already bifurcated city quadrants grew in disparity, complaints abounded about who Neighborhood Associations represented and benefited. Tensions grew as the city labeled activist neighbors unwieldy and reactive, while organizers "complained that the city increasingly was shutting the public out of important decisions" (Leistner 2013, 2-3).

The last major transitions, restructuring and evaluations of ONI and the efficacy of their community programs was conducted in 2005 under the direction of Mayor Tom Potter and his “Community Connect" project. While Potter's plan did much to identify choke-points of civic engagement and bring issues of disparate lived experiences within the city to the forefront of the public eye, the effects were short-lived, as subsequent mayors defunded and gutted his programs, as well as ONI itself. In the twelve years since the last assessments were made, Portland has entered into a severe crisis of racial tensions, lack of affordable housing and fundamental identity. Hate crimes since the 2016 Presidential elections are on the rise throughout the nation, but nowhere has seen as large of an uptick with as many crimes reported as the Portland Metro area. Organizers that once made the neighborhoods the bastions of participatory government are being priced out of the city and residents are evaluating its legitimacy much lower than ever before. 


\section{METHODS}

For this study I chose a Multi Method Research (MMR) approach that combined historical and comparative case studies of two cities, along with statistical cross tabulations and analysis of covariance from a small-n survey administered within them both, each just before a highlycontested presidential election. The survey instrument seeks to expose commonly held perceptions by residents of each city about their trust in their local government, while the case studies seek to construct the story of the material and intangible conditions that may have led to those opinions. However, just as this thesis suggests a need to begin to consider public policies and participatory programs as products of the socioeconomic paradigm in which they were created, so too my methodology seeks to practice new ways to approach the research that begins to unpack those considerations, and to examine the metaphysical and ontological origins of its own presumptions. While MMR is hardly new in terms of research practices, the largely inductive approach that I utilized and layout below is unconventional, to the best of my knowledge, and deliberately executed for its humble utility as a stage-setter for future inquiry.

Rather than focus on definitively identifying the causal mechanisms or processes that undergird my research questions, as is normally the case with approaches like comparative case studies, my research seeks to incrementally unpack the inductive regularities that tie these case studies to their corresponding survey answers, so as to begin to construct the story of what people think and feel about their relationships to their government in these different contexts. This research marks the beginning of my inquiry into the subjects discussed throughout this paper, with the ultimate desired result of future research being the formulation of best practices 
for creating truly meaningful participatory programs that further decentralize government at the local level, raise evaluations of legitimacy and increase individual capacity for communitydriven self-determination.

In other words, just as my findings suggest that meaningful participation in programs of decentralization need to be designed and decided-upon in an upwards fashion, originating from the participants' engagement, so too did I wish to construct a methodology that begins to tell the story of legitimacy from the ideations and viewpoints of the participants up. As Daniel Little explains in Varieties of Social Explanation, "The construction of a causal story based on a particular case, then, requires two things: fairly detailed knowledge about the sequence of events within the large historical process and credible theoretical or indicative hypotheses about various kinds of social causation" $(1991,30)$. It is my hope that the preceding literature review of legitimacy and civic engagement serve as the established empirical regularities under which the conditions of my inductive explanation may be subsumed (Little 1991, 7). ${ }^{6}$

In the aforementioned pursuit, I created a survey instrument (see Appendix) that assessed several variables including demographics, perceptions of self, of local institutions and of trustbuilding, participatory activities. For control purposes and exploring causal relationships, basic demographics included gender identity, age, monthly salary, and political affiliation if any. Demographics were included in order to determine whether they affect levels of trust in government or ideas of desired arrangements of inclusion in governmental processes. Beyond those basic demographics the survey assessed whether or not the respondent considers

\footnotetext{
${ }^{6}$ For a richer understanding of both my ontological and epistemological approaches, I also offered the discussion concerning philosophical understandings of different research methods within the section "Philosophy of Methodology" on page 35 above.
} 
themselves a "civically engaged" person, and if so, how they are civically engaged and with what frequency.

The more substantive portion of the survey was divided into two questions and a prompt, itself consisting of three pertinent questions. The initial question asked whether or not the respondent has confidence in their "city's ability to govern and provide for its citizens," or if they believe that "other institutions like NGOs are better at addressing citizens' needs and interests. This question served a dual purpose. First, it examined the respondent's individual assessment of their government's abilities to perform its functions and, thereby, begins to inform the story of legitimacy. As mentioned within the literature review, factors that are known to induce consent from constituents include the belief in the capacity of the government to fulfill its duties, as perceived by the person or community giving consent to be governed (Copeland 1991, 42). The second purpose of this question was to examine the difference in responses between Rosarians and Portlanders, given the dissimilar relationships with nonprofit and nongovernmental organizations that each city experiences within their local and national contexts.

Building upon those responses, the second question seeks to ascertain whether or not the respondent's trust in their city government would increase if they were able to be involved in "its processes beyond voting." The aim of this inquiry is simple: do people with low trust in their government feel that that their involvement beyond just voting would add capacity and elements that would incur more trust within that government? Isolating the answers to this question from respondents that indicated that they do not currently trust their government helps to further 
elucidate what opportunities are missing from current civic engagement that could otherwise increase government legitimacy - in this case, the opportunity to be involved beyond voting.

Lastly, respondents were prompted to imagine that their, "local government is crafting major changes to public policy and is looking for citizen input. The plan will affect public transportation, housing and security. You have the opportunity to get involved in the decisionmaking process." The questions that follow the prompt ask three things: (1) whether the respondent would be more likely to participate in involvement that engaged other city residents "in person (for example at an open meeting)," "over the internet (for example in an online discussion forum or opinion poll)," or if they would prefer to decline participation; (2) considering the same options (in person or online), respondents were asked which type of involvement would most increase their trust in their city government, with the option to choose neither; and lastly (3) respondents were asked which type of opportunity for citizens to become involved in the process from the prompt would increase their trust in government more - a citizen advisory group that shares decision-making power with city officials or one that offers opinions to city officials, but has no decision-making powers (or, of course, "neither").

The pertinence of the last set of questions is significant. As noted throughout the sections above on legitimacy, civic engagement, participatory governance and decentralization, not all participation is created equally and not all residents will experience the benefits and points of access to that involvement equally. It is therefore necessary, when beginning to gauge the opinions and evaluations that people hold conceptually, to not assume that the same person might choose the same answer to questions of which types of involvement may increase their trust 
more and which types of involvement they would be most likely to engage. In fact, finding the discrepancies between those answers from individual respondents, or between residents of different cities, might provide a large portion of the necessary inductively-acquired elements from which a story that points to potential causal correlations might be built.

The surveys themselves were administered in the highly-frequented public riverside parks in both cities - in Rosario at Parque España on the Rio Paraná and in Portland on the west side of the Willamette River, in the Tom McCall Riverfront Park. Interestingly, both parks have histories steeped in intentional city planning with some aspect of decentralized governance and/or participatory governance involved. (Reid 1925; Leistner 2013; Saunier and Ewen 2008). They are also both hubs of diverse social interaction in their respective city, offering free space for congregation that is accessed by residents of all socioeconomic statuses, as well as genders and ethnic backgrounds. In fact, neither city has more of a "melting pot" location outside of their business/night club downtown centers or sports arenas, as they do in their riverside parks. In each city, random persons in the park were approached and asked to fill out the survey over several days - both during the week and on the weekends - and at different times of day, so as to get the most random sampling of respondents possible via this method.

While the sampling was not as randomized as it could have been, nor do the numbers of completed surveys constitute the 200-300 minimum for the delineation of large-n statistical analysis, the sampling served its purposes for my intention to begin my research and to assess some opinions and perspectives of random residents within each city. After entering all of the data from those surveys that were completed correctly (at least mostly complete, with directions 
followed and absent obstructive error) into SPSS software, I was able to run cross tabulations on the answers and to control my analyses for several different potentially causally correlated variables.

Included in my findings are the results of two variable adjustments worthy of mention. First, when asking whether respondents have confidence in their city or in other institutions "like NGOs" the option was given to also express confidence in "neither." For the purpose of gauging general attitudes, those responses of "neither" were collapsed into the preference for NGOs to express a single variable response of, "no," to the question of whether the respondent has confidence in their local government. Secondly, as a novice at survey instrument creation, I made the mistake of not standardizing levels of income between Rosarians and Portlanders before creating the survey ranges. As such, I converted the monthly salary ranges of Rosarians into the income levels reflected based on median income levels, minimum wages and average cost of living for the city, to create a scale of approximate income levels commiserate with the norms in the United States. Unable to find specific information for minimum wage in Rosario, I relied upon the the reported minimum salary in Buenos Aires, as economic levels are completely comparable there, as is cost of living. I completed the same sort of extrapolation for wages in Portland, in both a state and national context in Oregon and the U.S. ${ }^{7}$ It also bears mentioning that, while race is an important factor for tensions and low approval ratings in Portland, it is not measured within this survey instrument because of its lack of significance as a variable in Rosario.

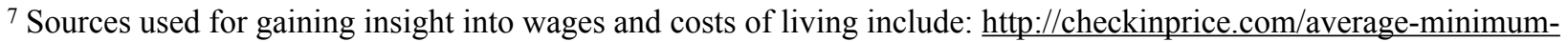
salary-buenos-aires/, http://www.oregonlive.com/business/index.ssf/2016/05/middle_class_declines_in_orego.html; https://www.numbeo.com/cost-of-living/in/Buenos-Aires.
} 


\section{FINDINGS}

GENERAL FINDINGS

A total of 127 valid $^{8}$ surveys were completed, with 69 gathered in Portland, Oregon and 58 in Rosario, Santa Fe. As indicated in the methods section, all surveys were gathered in hightraffic public parks near each city's major river, during the final 2-3 weeks before major federal, regional and local elections took place in each country, state, province and city, respectively. Of those that participated, 53.5\% identified their sex/gender as "Female", 33.1\% as "Male", 3.1\% identified as "Non-binary" and $1.6 \%$ as "Other," with $8.7 \%$ declining to answer all together, as seen in Figure 1. Figure 2 shows respondents varied in age from $13^{9}$ to 74 , with $51.7 \%$ aged 29 or younger, and a mean age of just under 34 years. In Portland, most respondents (66.7\%) were considered low-income, with just $31.7 \%$ within the low-to-high Mid-Income range, and just 1.7\% identified as High-Income, as you can see in Figure 3. Figure 4 shows in Rosario, though, respondents were nearly equally represented between the Low Income (37\%) and Mid to HighMid Income (39.1\%) ranges, with 19.6\% falling in the Low-Mid Income range and 4.3\% representing High-Income earners. Without any general definition or parameters provided as qualifying civic engagement within the instructions on the survey, $46.5 \%$ of respondents considered themselves civically engaged, with $60 \%$ reporting that they attend 1 to 2 meetings/

\footnotetext{
8131 surveys were collected in total, but 2 were left mostly-blank with only one or two answers given and 2 were filled out mostly incorrectly, with little-to-no usable data, so they were omitted from the final results.

${ }^{9}$ Only 3 respondents were less than 18 years of age, with two at 13 years old and one at 17 . All three were respondents in Rosario, Argentina in which, due to its recent history of repressive regimes, its current commitment to political education in primary and secondary schools, and its mandate of compulsory voting, teenagers generally seemed to me to have a greater awareness of voting as a mechanism for civic engagement, as well as the politicians and parties involved in elections than their U.S. counterparts. As such, I've chosen to include their surveys.
} 
events pertaining to their civic engagement per month, and $10 \%$ reporting attendance at more than 5 meetings per month.

While there are also findings pertaining to respondent's political party affiliation (or lack thereof), those results are included and briefly discussed in Appendix C, instead of in this section or the formal discussion section, due to the wildly different nature of the political party systems in each city and nation. Here I will note that both Rosario and Portland are known to be leftleaning within their national context - more so than just the average urban area.

\section{CONFIDENCE IN CITY GOVERNMENT}

The first measure of significance that the survey explored was whether or not the respondent had confidence in their, "city's ability to govern and provide for its citizens," or if they believed that "other institutions like NGOs are better at addressing citizens' needs and interests?" The initial frequency distribution of this question demonstrated that just over half (52.1\%) of respondents from both cities do have confidence in their city's ability to govern and provide, with $22.3 \%$ indicating that they have more confidence in NGOs and other institutions, and $25.6 \%$ indicating a lack of confidence in either city government or other institutions. In order to better compare the findings throughout the data analysis, responses in favor of NGOs or that indicated trust in "neither" option were collapsed into one overall "no" response (as explained in the methods section) ultimately yielding Figure 5, which shows nearly half (47.9\%) of respondents indicated that they do not have confidence in their city government. Broken down by city, $49.3 \%$ of Portlanders trust their city government compared to $55.8 \%$ of Rosarians.. 
Women and men had nearly opposite self-assessments of their confidence in their city governments, with women reporting $59.4 \%$ confidence and men at $56.1 \%$ no confidence across both cities. Non-binary respondents indicated only $25 \%$ confidence in their city governments, with those identifying as "Other" split equally at 50\% "yes" and "no." By city, however, the disparity between genders was much more stark in Rosario than Portland. In Portland, 54.8\% of women expressed confidence in their city government, with men split equally at 50\% "yes," and "no," respectively, while in Rosario women expressed 63.6\% confidence and men 69.2\% lack thereof.

Considered across both cities, each of the five different age groups expressed a majority of confidence in their city government except the age bracket of 19-32 years old. In both cities the youngest (age 18 or younger) and two older brackets of ages (47 to over 61 years old) expressed the most confidence in their city governments, with $60 \%$ of the age group of $33-46$ expressing confidence in their city governments in each city. There are two major divergences of note from the aggregate trends that appear within each city. First, in Portland, $0 \%$ of respondents aged 47-60 years expressed confidence in their city government. However, confidence in the same age group in Rosario was so robust (87.5\%) that it created an overall dispersion of trust across both cities in that age group of $63.6 \%$, when aggregated. Another divergence of note is that, while in both the Portland results and across both cities considered together, levels of confidence are the highest in the youngest and oldest age brackets, in Rosario confidence falls by nearly $2 \%$ from the second oldest age bracket (discussed above), to the oldest. The implications 
of these differences, as with all others, will be explored thoroughly in the discussion section below.

When examined by income level, both Low Income and Low-Mid Income respondents expressed a lack of confidence in their city government, versus their Mid through High Income counterparts. Only when controlling for city did this trend deviate in Rosario's results, in which confidence in city government is expressed only within the Mid to High-Mid Income bracket, with High Income respondents also expressing a lack of confidence in city government, akin to their Low Income counterparts. Table 1 reflects confidence by income level.

ATTITUDES TOWARDS INVOLVEMENT

After gauging whether respondents possessed confidence in their city governments, the survey sought to determine if respondents would experience an increase in that confidence if they "could be more involved with its processes beyond voting. Then they were encouraged to imagine a scenario in which their local government was crafting major changes to public policy, seeking citizen input and offering opportunities to get involved in the decision-making process. Respondents were asked three questions to determine: (1) which type of involvement they would be most likely to participate in, (2) which type of involvement with other city residents would increase their trust in their city government - either in person or online, and (3) whether involvement in a citizen advisory group that shares decision-making powers with city officials or one that offers opinions to them would increase their trust more. The data was cross tabulated 
and compared, controlling for city of residence, gender, level of trust in city government and income. Tables 2 through 7 reflect the attitudes towards involvement discussed below.

Nearly three quarters (74.6\%) of all respondents said that involvement beyond voting would increase their trust in their city government. Of the $47.9 \%$ of respondents across both cities that indicated they do not have confidence in their city governments, $70.2 \%$ reported that increased involvement beyond voting would increase their trust in their city government. Enthusiasm for increased involvement beyond voting was higher in Portland than in Rosario. In Portland, $73.5 \%$ of those that did not have confidence in their city government indicated that their trust would increase along with increased involvement, while $85.3 \%$ of those that already held confidence in the city also said that increased involvement would increase their trust. In Rosario the trends were the same but the numbers were lower with $65.2 \%$ of those that did not have confidence believing that their trust would increase with increased involvement, and 69\% of those that did already have confidence anticipating an increase in their trust according to increased involvement.

Preference for the type of engagement respondents would be most likely to participate in was almost evenly split across the cities, with $44.6 \%$ selecting an in-person arrangement, "like in a meeting," and $43.8 \%$ electing to engage online, "through a poll or discussion," with $11.6 \%$ electing not to participate at all. When considering existing confidence in their city government, those that already possessed it were more inclined (at $49.2 \%$ ) to engage in person, while $45.6 \%$ of those that do not trust the city would opt to participate online or, at $15.8 \%$, would choose not to participate at all. This disparity intensified in different ways at the city level, where in Portland 
the same trend was magnified, and in Rosario preferences for online involvement were stronger. Across the gender spectrum, every group that also did not hold confidence in their city government indicated that they would be more likely to engage online or not participate at all than meet in person, except for men who were split equally (at $40.9 \%$ ) between in person and online. Of greatest note in terms of income bracket, Low Income respondents were more likely to participate in person regardless of whether or not they trusted their city governments, while $100 \%$ of High Income respondents opted for online involvement.

Despite only $44.6 \%$ of respondents indicating that they'd be more likely to engage in person themselves, $63.9 \%$ of all respondents indicated that doing so would increase their trust in government more than engaging online. The majority of those respondents that do not hold confidence in their city governments - across all cities, genders and income levels - believe that engaging with other citizens in person would increase their trust more than engaging with them online, except for respondents identifying as non-binary and all respondents within the high income bracket who, as noted above, would not opt to engage in person at all. The same also holds true for all respondents who do possess confidence in their city government, except for Rosarians who tend to more highly esteem online interaction and involvement, and High Income respondents with trust in government, who are split 50/50 between in person and online.

Just as in the case with in person involvement, nearly two thirds of all respondents (74\%) indicated that group involvement that included shared decision-making power with city officials would increase their trust in their city government more than an advisory group that shares opinions with city officials. This sentiment was also the most significantly shared by respondents 
of all cities, gender identities and income brackets, who did not have confidence in their city government. Non-Binary and "Other" identified gendered respondents only selected shared decision-making power, regardless of whether or not they held confidence in their city already and, again, only High-Income respondents indicated that an advisory role would increase their trust in city government more than shared decision-making powers. 


\section{DISCUSSION}

The socioeconomic and political importance of cities on the global stage continues to rise and with it, the decentralization and push towards democratization of local governments is proliferating. At the same time, a more connected and informed citizenry is losing confidence in government structures, service delivery and patience as decades of neoliberal practices continue to result in ever-more-disparate income inequality and standards of living. Though legitimacy can be conferred coercively without attitudes of confidence or trust bestowed upon a government by an electorate, studies show that greater satisfaction with government efficacy produces increased legitimacy and stability in democratic regimes. In order to devise policies, programs and partnerships that will re-instill and sustain confidence in increasingly-relevant, democratic local government, policy makers may seek to understand the perceptions, attitudes and desires of municipal communities regarding their involvement in the plans that effect them most.

One way to evaluate best practices while simultaneously finding opportunities for growth and development in new directions is to assess the attitudes of those most dis-heartened and disillusioned within those cities that are most widely-lauded for their participatory governance, decentralization and civi engagement. It is in this vein - for their international notoriety as exemplars of innovation in civic engagement - that attitudes of residents in both Portland, Oregon and Rosario, Santa Fe were surveyed.

The results of the surveys support previous findings in the literature concerning attitudes of low-income residents and an association between increased involvement in governmental decision-making and increased trust in that government. In addition to supporting previous 
findings, the above results also reflect new findings in preferences for online or in-person engagement and offer new opportunities for inquiry into the institutional and cultural differences that might explain disparities in those preferences between income brackets and different cities.

\section{CONFIDENCE IN CITY GOVERNMENT}

When aggregated, the survey results regarding residents' confidence in their city government support the existing literature that frames my claims in several important ways. First, reports of confidence in both city governments from the survey are much higher than those reported from overall national averages. The $49.3 \%$ of respondents in Portland and $55.8 \%$ of respondents in Rosario far outshine the national trends of overall confidence in government reported at roughly 20\% in the United States (Public Trust 2017) and 37\% in Argentina (AmericasBarometer 2016). This supports the rising relevance, and greater potential, of local governments to increase public participation than their national counterparts, as well as their ostensible levels of legitimacy in the eyes of their residents. Moreover, my results indicate that Low to Mid-Income respondents possess significantly less trust in their city governments than wealthier respondents, which supports findings from the literature discussed that programs to increase civic engagement do not necessarily reach, support or reflect the needs and interests of Low to Mid-Income residents in meaningful ways.

When considered on a city-by-city basis, however, discrepancies between my predictions of confidence and what the data bears out begin to emerge. For example, when considered with recent reports on general attitudes towards local governments in each respective country, the 
survey results that I gathered in the United States indicate that Portlanders' $49.3 \%$ confidence in is well below the national average of $71 \%$ confidence at the local level (Public Trust 2017). This finding alone would further support the claim that programs to increase civic engagement and participation that are in practice - even in those cities like Rosario and Portland that are most well-known for their efforts in decentralization - are not doing enough to meaningfully sustain evaluations of confidence from their residents. However, Rosario's $55.8 \%$ of respondents reporting that they possess trust in their city government far outweighs the national averages of between 22\% and 37\% approval of local government in Argentina (Jorge 2009). This discrepancy could be attributed to institutional differences, such as the historically antiestablishment and anti-federal stance that Rosario's local government has taken throughout the years and is discussed in the literature review above. With clientelism and corruption so rampant in Argentina, the frequently-adopted position of Rosario's leadership to not be in bed with the federal government may have instilled more feelings of trust and evaluations of authenticity and legitimacy in Rosarians than in Portlanders, towards their city. Or, perhaps the proliferation of Presupuesto Participativo has been more effective than the programs in Portland to increase evaluations legitimacy and confidence within the community. Regardless of why it exists, the discrepancy suggests that some variable that increases trust in local government is actively at play in Rosario and absent from Portland.

It should be taken into consideration that the national-level surveys cited above from institutions like the Pew Research Center and the Corporación Latinobarómetro assessed levels of confidence with relative scales (i.e. Likert) that allowed respondents to denote a particular 
degree of confidence or trust in different levels of government (such as "Mostly Trust," "Somewhat Trust," etc...), whereas my survey instrument presented a more dichotomous choice that encouraged respondents to consider their confidence in their local governments relative to their confidence in NGOs or other institutions.

That being the case, though, the assertion that current programs and opportunities for civic engagement are not sufficient for cultivating sustained or increased confidence in city government is further supported by the cross tabulation and comparison of those respondents that consider themselves civically engaged with those that indicate trust in their city governments, or lack thereof. When compared, considering oneself civically engaged resulted in only a $2.3 \%$ increase in respondents with confidence in Portland's city government, and a 2.1\% increase in Rosario. This result affirms that the act of engagement (or perception of self as civically engaged) increases participants' confidence in their governments, but in the cases of Portland and Rosario, that perception of engagement does not result in an aggregated uplift of confidence in government significant enough to buck the overall national downward trend. So while programs in place might be helping, they certainly aren't helping enough to cultivate sustained legitimacy.

In this case, however, the findings could have been more meaningful if my survey instrument had included some standard definition of what it means to be considered "civically engaged," and/or could have included a more precise mechanism for measuring the type and level of involvement that respondents were engaged with on a regular basis. As it was, it is impossible to know if those respondents that consider themselves civically engaged are participating in government-crafted or sponsored activities like those I am seeking to evaluate. 
What I can ascertain from my more open-ended survey question is that the majority of those that both consider themselves civically engaged in Portland (64.3\%) and Rosario (50\%) and disclosed the frequency and type of their involvement reported being engaged in at least 1-2 nondescript meetings per month on average.

As mentioned in the findings, the aggregated data reveals that the age bracket of 19-32 years old is the only in which a majority of respondents did not express confidence in their local government. This Millenial bracket represents the oldest of the two age groups that were raised exclusively in the latter stages of global neoliberal socioeconomic policies. They are also representative of a generation raised with greater technological capacity and exposure to global media and information, while at the same time being the first generation of the modern era predicted to not improve upon the gains of preceding generation in terms of living standards. In short, the age bracket that indicates the least confidence in government is that bracket that has had its opinions influenced by more diverse sources than previous generations, and its options limited to less diverse opportunities, as a result of neoliberalism. If anything, this finding may suggest that the systems of public service delivery and public policies in place are not satisfactory to younger adult residents that are faced with trying to make more from less in a global economy that is becoming increasingly stacked against them.

\section{PREFERENCES FOR PARTICIPATION}

As discussed in this paper's introduction and literature review, thoughts and perceptions do not always seamlessly correlate with actions, and trust in government is not the only 
precondition for legitimacy. However, each of those variables can be strongly associated with the aforementioned outcomes, and it is with this understanding that I sought to assess residents' beliefs about their own needs and desires, as well as what they anticipate would most increase their trust in city government. The findings from my survey regarding attitudes towards involvement and preferences for participation strongly support my argument that increased participation - especially if made meaningful through shared decision-making powers with city government - is likely to increase trust in local government.

Not only did three quarters of respondents confirm that increased involvement beyond voting would raise their trust in their city government but, as reported in the findings, nearly the same amount of those who already lacked trust in their government anticipated that increased involvement would, too, raise their trust. This finding is significant because it signals that residents with little or no trust in their city government are open and willing to consider ways in which their trust might be increased. It is also significant because it holds across both cities when considered individually, though Portland does show $8.2 \%$ more proclivity to expect increased trust as a result of increased involvement. The high level of agreement that increased involvement beyond voting should result in increased trust in city government is made all the more interesting when considering how respondents indicate they'd most likely personally participate versus what type of participation would theoretically increase trust the most.

Even as much of the literature suggests that in-person deliberation and involvement increases a sense of connectedness, community and trust among participants from direct relationship-building, trends towards open government and e-participation are also on the rise, 
providing different types of opportunities for collaboration and participatory governance than ever before. It is important, then, when assessing attitudes towards involvement, to get a sense of which activities residents might be more inclined to participate in. In the context of this survey, the inclination to engage in person or online was relatively evenly split down the middle.

Across the board, those who already possessed confidence in their city were more inclined to participate in person, while those who did not were more inclined to be involved online or to not participate at all. Since the literature suggests that time-commitments, childcare and employment needs serve as barriers to participation for lower-income residents, this trend would make sense considering those that expressed confidence in their city in this survey also held higher income levels than those that did not. Surprisingly, though, Low Income respondents indicated that they would be more likely to participate in person regardless of whether or not they trusted their city governments, while $100 \%$ of High Income respondents opted for online involvement. These results could have several explanations/implications. First, this could again be an instance wherein respondents might think one way - that they would like to participate in person - but act another, due to obstacles or conditions that present in reality. If that is true, the fact that Low Income individuals indicate a greater willingness to participate in person bolsters the idea that what truly prevents that participation is a lack of ease of access and support in doing so more generally, which can greatly help to inform future policies and best practices. Also, while the literature suggests that higher-income residents or those with more free time like older, retired persons tend to be more civically engaged in person, the findings from this survey may belie a general antisocial or anti-civil quality that develops as a result of experiencing greater 
wealth in a system which inherently accumulates wealth at the expense of others. A 2012 study, for example, revealed that, "Privileged people behaved consistently worse than others in a range of situations, with a greater tendency to lie, cheat, take things meant for others, cut up other road users, not stop for pedestrians on crossings, and endorse unethical behavior," (Upper Class 2012). Perhaps the unanimous inclination towards online involvement on behalf of wealthier respondents is a result of antisocial conditioning?

In the future, a more precisely-developed survey instrument would be helpful in sussing out the nuance of responses like preference for participation, because when broken down by city, most Rosarians indicated a preference to engage online, regardless of income level or existing trust in government. This could be explained in a variety of ways. Perhaps civic engagement programs like participatory budgeting in Rosario have been so successful in person and have shown so much promise in developing mechanisms for online involvement that residents are eager to continue to breach newer frontiers and engage more virtually. Another explanation could be that, while residents in many liberal cities in the U.S. are galvanizing a renaissance of lowtech practices like homesteading, residents in other countries like Argentina that are experiencing more stable democracy, economic growth and the surplus of national wealth for the first time, might be more enamored with experiencing the latest innovations of technology in the public sphere. Some recent speculations by both the Financial Times and The New York Times attribute a greater affinity towards the internet, technology and start ups in Argentina to the culture of covert "hacking" that became prevalent in all sectors of public life during the repressive military junta (Mander 2016; Perlroth 2015). This area of inquiry begs further research as technology 
continues to emerge and, more often than not, lead the way in social innovations. If the residents of some cities are more inclined to participate in governance online, it behooves policy makers to understand why so as to inform best practices in programmatic development.

Lastly, any further exploration of this research topic or the themes explored herein should examine the attitudinal aspect of legitimacy and relationship with participation in cities and local areas in which civic participation is not already the norm - where civic engagement is low and not valued as a necessary precondition for legitimacy. Since participation in governing is strongly associated with favorable views of government, I would expect that such locales would have less-favorable views of their government. Also, based on the greater attitudes towards the trust-bolstering effects of participation from respondents in this study who already hold lower views of their government, I would expect that the effects of increased participation in areas where trust and evaluations of government is low to follow suit and be even more bolstered by greater involvement and opportunities to affect their material conditions meaningfully.

\section{SIGNIFICANCE}

The results of the survey administered in this study open many more questions for future research, and also corroborate recent findings that - while efforts towards increasing civic engagement and participatory governance are working to increase levels of confidence in city governments - they are not working nearly well enough to ensure that evaluations of legitimacy keep pace with growing gaps in wages, quality of life and access to services. As the chasm deepens globally between those who have and those who have not, opportunities to engage 
citizens before they become completely disenfranchised grow further and farther between. If cities stand a chance to make the most of their growing relevance, they must devise mechanisms to instill perceptions of their legitimacy within their residents in a lasting, sustainable way. This conclusion is in no way new - mine is not the first study, by any means, to point out the deficits of equitable democracy that still exist, despite the best efforts of policy makers seeking to decentralize and equalize the proverbial playing field. Why then - even with so much attention given to the plight of legitimization through decentralization by reputable, international institutions - do so many programs to increase participation in local governance so regularly miss the mark?

While my survey instrument may contribute in a minor way to the wealth of substantiated information that already exists within this discourse community, this paper seeks to beg the above question from a new perspective - one that examines the theoretical and ontological roots of the containers in which participatory governance programs are devised. More specifically, by laying bare the value of perceptions of legitimacy to a ruling regime, the history of decentralization, civic engagement and participatory governance as reactions to failed neoliberal practices of political professionalization and consolidation, alongside prevailing sentiments of mistrust and disengagement in those cities that would be expected to boast the most confidence in their governments, I have built the beginnings of an argument that seeks to unveil the greatest obstructions to democracy and justice that inhibit a more equitable future: namely, neoliberalism, capitalism and the privatized, consolidated state. 
Whereas most case studies discussed earlier in this paper and throughout much of the available literature offer critiques of public management practices in and of themselves, my view wrests those pinch-points in a potentially much more effective network of inclusion as symptoms of a greater systemic illness. When neoliberal economics defund our public services and capitalism lays waste to the commons, governments are forced to seek private funding, nonprofit collaboration, and to further complicate the administration of historically overly-bureaucratized structures of organization. As a practice, local governments have habitually turned to academic and professional "experts" to devise programs to democratize and decentralize the provision of governmental goods and services. However, as the literature review, case studies and my original research suggest when considered together, those programs are not working to adequately involve, reflect or meaningfully engage the residents that need the most of what local government has to proffer.

I assert that the reason for this stagnation is because those programs practiced have been designed within a paradigm that ultimately not only shares the infrastructure created under influences of neoliberalism, capitalism and its ensuing political professionalization, but also the core values that drive those machines: the valuation of profit above all else. As Kim et al state, “...the design of institutions is a political process, whose effectiveness rests neither on the formal validity of technocratic approaches, nor on the abstract value of externally-driven, decontextualized reform packages. Strengthening democratic institutions and building the conditions for democratic politics are two inter-related aspects of democracy building" (2005, $53)$. 
Thus far, the most renowned programs in civic engagement and participatory governance have been designed by experts, only marginally served the needs of the communities they purport to, and in many cases have been distinguished by laudatory rhetoric and lofty aspirations instead of actual gains or innovations. Their potential as systems of change has been eclipsed by their utility to generate investment and wealth in a system that fundamentally cannot allow agents of change to thrive - or even survive.

The substance of the initial question of legitimacy, the findings of these and other case studies and the questions that they, in turn, inspire regarding local government funding and decision-making processes require much more time and consideration than this paper allows. Ending with the question of the actual relevance of local government legitimacy, I would like to posit that local, sub-national governments will be more important now than ever in keeping the peace in an increasingly divided populace, both in the United States and throughout the democratized world. As political divides reach historic proportions and global warming threatens each municipality in different ways, local governments will be posed with ever increasing issues of security and safety, some even mirroring those encountered regularly at the national level. In times of crises it is of utmost importance that governance not only remains good, open and inclusive, but also that its authority to keep peace and safety as a standard for its population is respected, obeyed and upheld. If cities do not follow emerging best practices in incorporating their citizens in their decision-making processes, they run the risk of being considered illegitimate and of being replaced by a new social order (Weber, 1947; Gilley, 2016). 
Furthermore, as our nation in particular deals with a neoliberal version of establishment politics that has failed its citizenry on both sides of the political debate, new avenues for increasing legitimacy at all levels of government need to be explored. Building upon the successes of platforms to increase democratization at the local level, national level governments may learn from the case studies of Sweden and elsewhere, how to appropriately and effectively incorporate their electorate into increased positions of perceived ownership of the democratic process. In so doing (and somewhat ironically) by increasing the power of citizens in the decision-making process, the government may actually have a fighting chance at maintaining and increasing its own power and relevance in the ever-evolving structures of general governance. 
Disclaimer: This survey is conducted for the purpose of an undergraduate thesis in the Political Science Honors program at the Hatfield School of Government. All of your responses will be kept confidential, with no identifying personal information reported or recorded.

1) In general, do you have confidence in your city's ability to govern and provide for its citizens, or do you believe that other institutions like NGO's are better at addressing citizens' needs and interests?

Yes, I have confidence in my city's ability to govern and provide for its citizens

No, I believe NGO's and other institutions are better at addressing citizen's needs and interests

I don't have confidence in either

2) Would you trust your city government more if you could be involved with its processes, beyond voting?

Yes _ No _ _ It doesn't matter

3) Imagine that your local government is crafting major changes to public policy and is looking for citizen input. The plan will affect public transportation, housing and security. You have the opportunity to get involved in the decision-making process.

Which type of involvement would you be more likely to participate in?

Engaging with other Portlanders in person, (for example at an open meeting)

Engaging with other Portlanders over the internet, (for example in an online discussion forum or opinion poll)

I w would prefer not to participate at al

Which type of involvement would increase your trust in your city government more? Engaging with other Portlanders in person, (for example at an open meeting)

Engaging with other Portlanders over the internet, (for example in an online discussion forum or opinion poll)

_ I would prefer not to participate at all

Considering the following ways citizens could be involved with this process, which way would increase your trust in your city government more?

The existence of a citizen advisory group that shares decision-making power with the city officials or

The existence of a citizen advisory group that offers opinion to city officials, but has no decision-making powers

_Neither 


\section{APPENDIX B \\ Rosario Survey Instrument}

\begin{abstract}
Programa de Intercambio Cultur: - U.N.R -Cuestionario-

1) En general, ¿tenés confianza en la capacidad del gobierno municipal de gobernar y administrar bien para los ciudadanos, o creés que otras instituciones como ONGs son mejores para comprender las necesidades e intereses de los
\end{abstract} ciudadanos?

Sí, tengo confianza en el gobierno municipal para gobernar y administrar bien para los ciudadanos. No, creo que las ONGs y otras instituciones son mejores para comprender las necesidades e intereses de los ciudadanos. No tengo confianza en ninguna.

2) ¿Confiarías más en el gobierno municipal si pudieras participar en los procesos de gobierno, además de votar?

$$
\text { Sí // }
$$
No // No importa.

3) Imaginá que tu gobierno municipal planea grandes cambios en sus políticas públicas y necesita de opiniones particulares. El plan afectaría el transporte público, la vivienda y la seguridad. Y tendrías la oportunidad de participar en el proceso de toma de decisiones.

¿Qué clase de participación tendrías? Consultar a otros rosarinos en persona (por ejemplo en una reunión pública) Consultar a otros rosarinos a través de internet (por ejemplo en un foro de discusión online o una encuesta) Preferirías no participar.

¿Qué clase de participación acrecentaría tu confianza en el gobierno municipal?
Consultar a otros rosarinos en persona (por ejemplo en una reunión pública) Consultar a otros rosarinos a través de internet (por ejemplo en un foro de discusión online o una encuesta) Preferirías no participar.

Considerando los siguientes modos en que los ciudadanos pueden participar en estos procedimientos, ¿de qué modo incrementarías más tu confianza en el gobierno municipal?

Mediante la existencia de un grupo de consejeros ciudadanos quecomparta poder de decisión con funcionarios municipales, o

Mediante la existencia de un grupo de consejeros ciudadanos que ofrezca sus opiniones a funcionarios municipales, pero que carezca de poder de decisión Ninguna.

\section{Datos Demográficos}

Nombre:

Edad:

Sexo:

Salario promedio: $\$ 0$ a $\$ 5.000 ; \$ 5.000$ a

$\$ 10.000 ; \$ 10.000$ a $\$ 20.000 ;+\$ 20.000$

¿Partido político?

¿Se considera una persona cívicamente comprometida? Si o No?

Si marco Si, por favor explique brevemente (Por ejemplo, como está comprometida, con qué partido o grupo político y con qué frecuencia):

MUCHAS GRACIAS! 
All Figures and Tables

Figure 1

Sex/Gender Identification

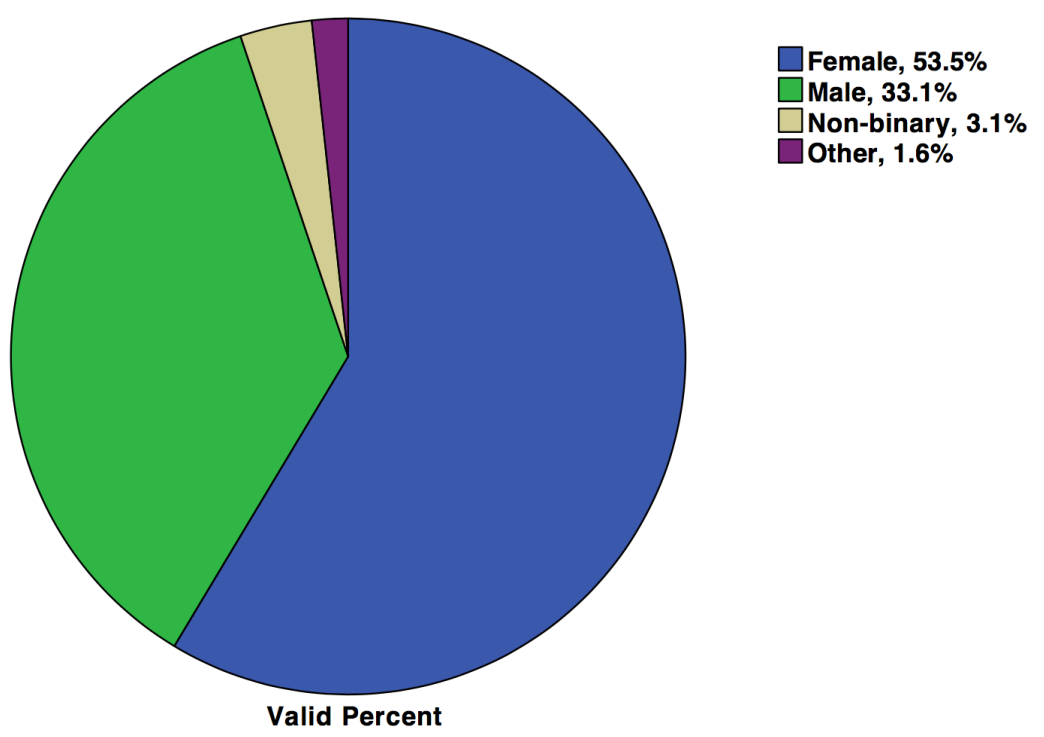

Figure 2

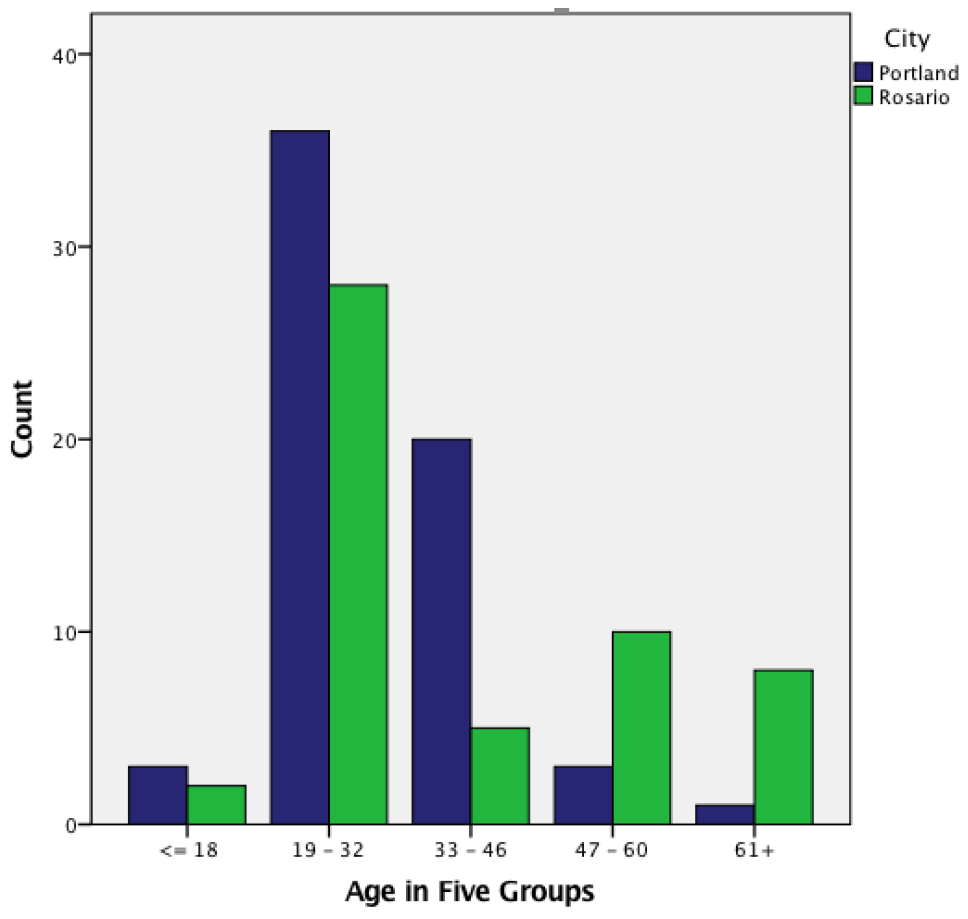


Figure 3

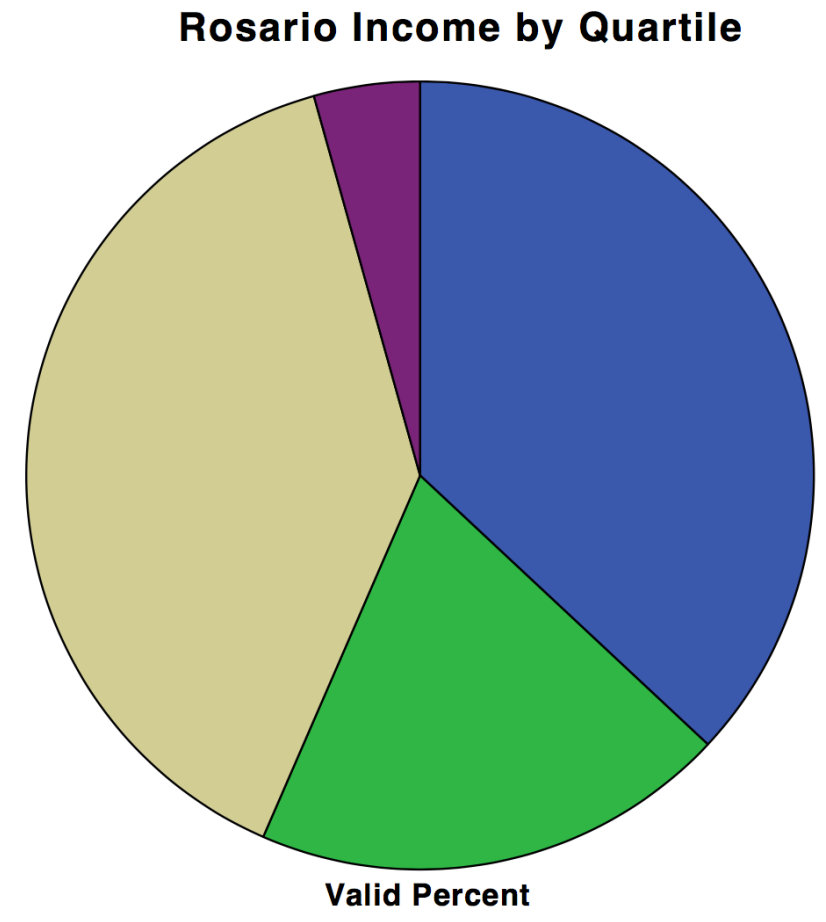

$\square$ Low Income - 37\% Low-Mid Income $19.6 \%$ $\square$ Mid to High-Mid

Income - 39.1\%

High Income -

$4.3 \%$

Figure 4

Portland Income by Quartile

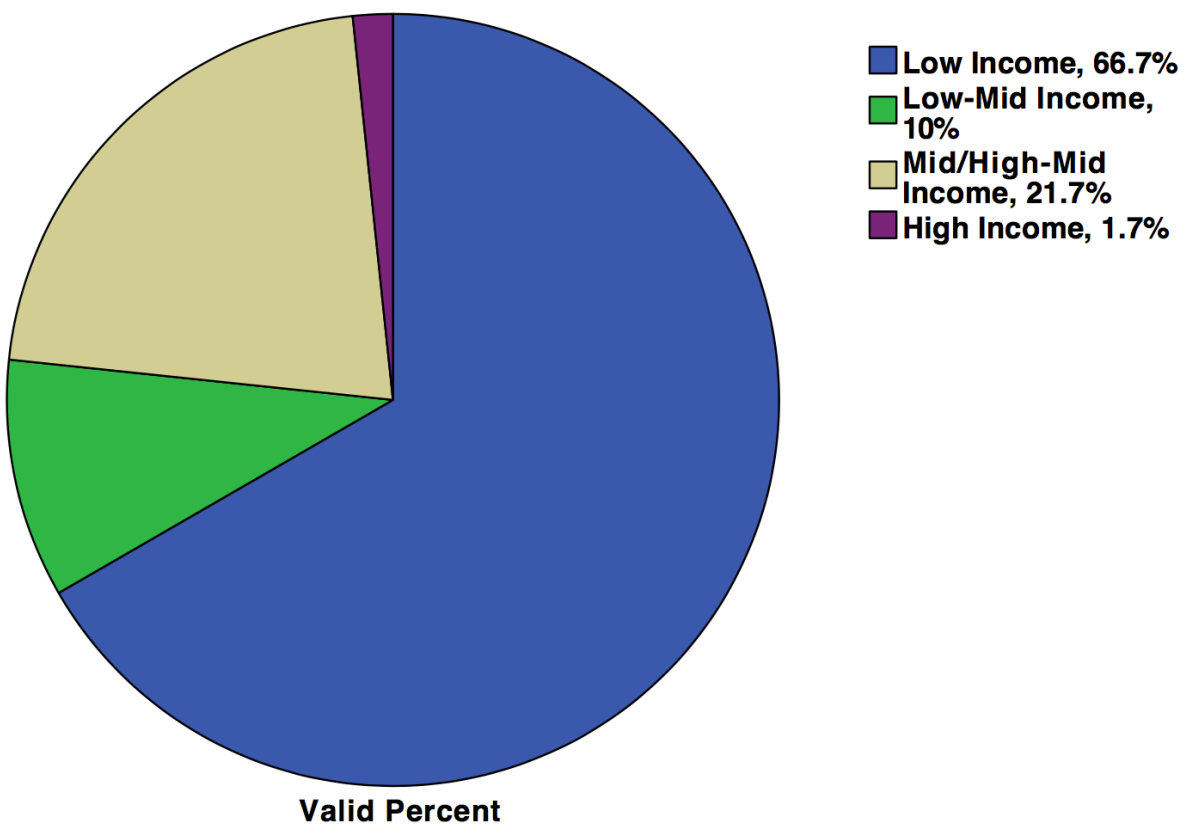




\section{Figure 5}

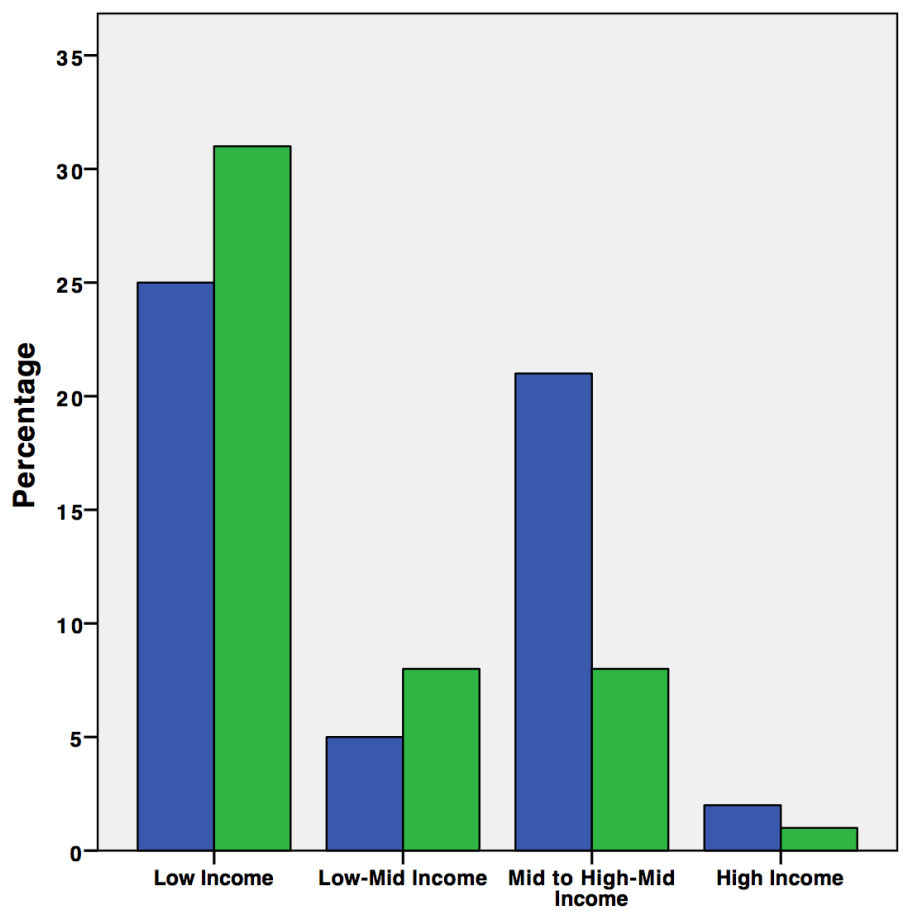

Do You Have Confidence in Your City Government?

$\square$ yes

Income Quartile Combined

Table 1

Confidence in City Government by Income Level and City

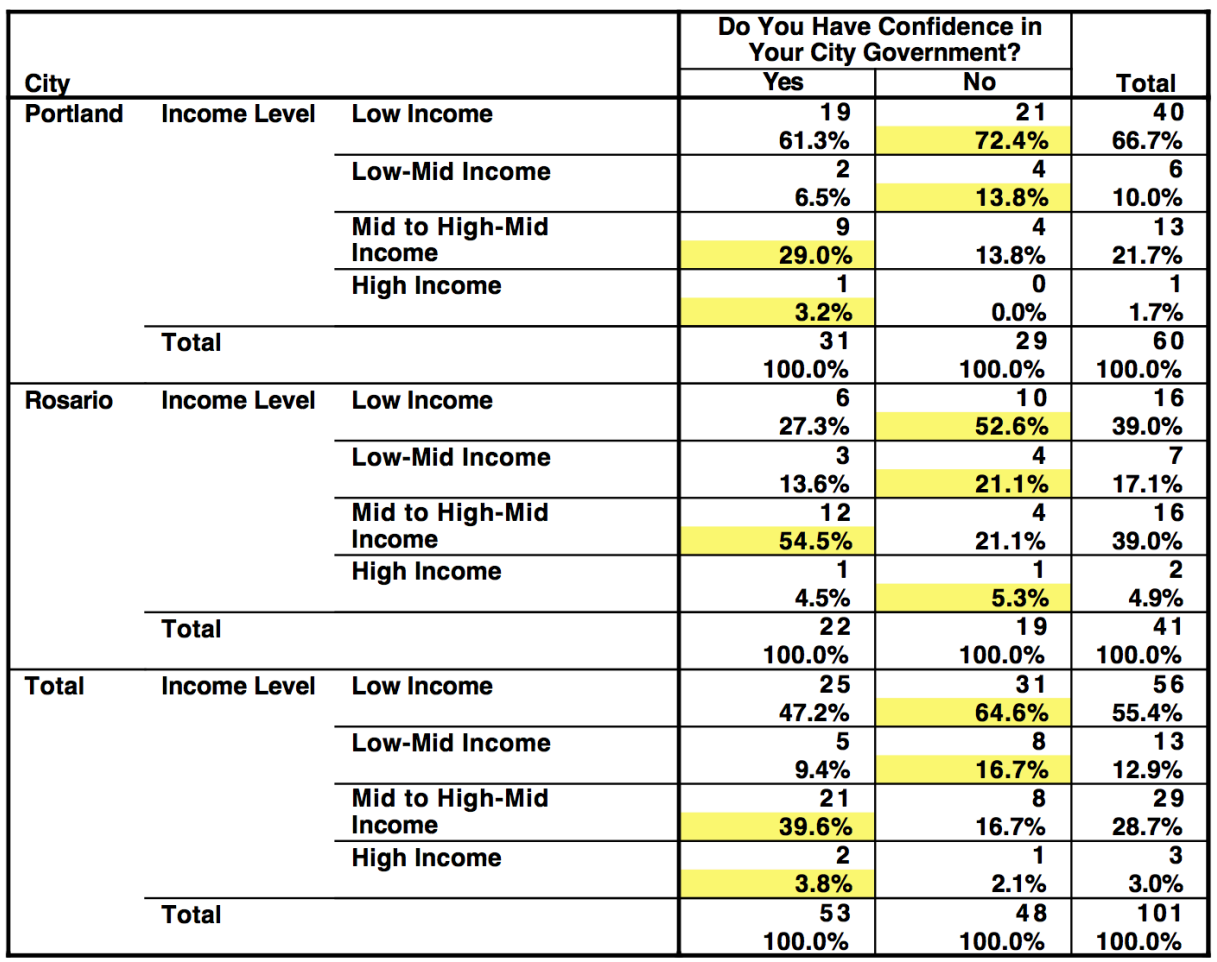


Table 2

Which Type of Personal Engagement Would Increase Your Trust in Your City Government More?

\begin{tabular}{|c|c|c|c|c|c|}
\hline \multirow[b]{2}{*}{ City } & & & \multicolumn{2}{|c|}{$\begin{array}{c}\text { Do You Have Confidence in } \\
\text { Your City Government? }\end{array}$} & \multirow[b]{2}{*}{ Total } \\
\hline & & & Yes & No & \\
\hline \multirow[t]{4}{*}{ Portland } & \multirow{3}{*}{$\begin{array}{l}\text { Type of Personal } \\
\text { Engagement That } \\
\text { Would Increase } \\
\text { Trust? }\end{array}$} & $\begin{array}{l}\text { With Others In } \\
\text { Person }\end{array}$ & $\begin{array}{r}27 \\
81.8 \%\end{array}$ & $\begin{array}{r}23 \\
69.7 \%\end{array}$ & $\begin{array}{r}50 \\
75.8 \%\end{array}$ \\
\hline & & With Others Online & $\begin{array}{r}4 \\
12.1 \% \\
\end{array}$ & $\begin{array}{r}4 \\
12.1 \% \\
\end{array}$ & $\begin{array}{r}8 \\
12.1 \% \\
\end{array}$ \\
\hline & & $\begin{array}{l}\text { Prefer Not to } \\
\text { Participate }\end{array}$ & $\begin{array}{r}2 \\
6.1 \% \\
\end{array}$ & $\begin{array}{r}6 \\
18.2 \% \\
\end{array}$ & $\begin{array}{r}8 \\
12.1 \% \\
\end{array}$ \\
\hline & \multicolumn{2}{|l|}{ Total } & $\begin{array}{r}33 \\
100.0 \% \\
\end{array}$ & $\begin{array}{r}33 \\
100.0 \% \\
\end{array}$ & $\begin{array}{r}66 \\
100.0 \% \\
\end{array}$ \\
\hline \multirow[t]{4}{*}{ Rosario } & \multirow{3}{*}{$\begin{array}{l}\text { Type of Personal } \\
\text { Engagement That } \\
\text { Would Increase } \\
\text { Trust? }\end{array}$} & $\begin{array}{l}\text { With Others In } \\
\text { Person }\end{array}$ & $\begin{array}{r}11 \\
44.0 \% \\
\end{array}$ & $\begin{array}{r}13 \\
56.5 \% \\
\end{array}$ & $\begin{array}{r}24 \\
50.0 \% \\
\end{array}$ \\
\hline & & With Others Online & $\begin{array}{r}13 \\
52.0 \%\end{array}$ & $\begin{array}{r}6 \\
26.1 \%\end{array}$ & $\begin{array}{r}19 \\
39.6 \%\end{array}$ \\
\hline & & $\begin{array}{l}\text { Prefer Not to } \\
\text { Participate }\end{array}$ & $\begin{array}{r}1 \\
4.0 \%\end{array}$ & $\begin{array}{r}4 \\
17.4 \%\end{array}$ & $\begin{array}{r}5 \\
10.4 \%\end{array}$ \\
\hline & \multicolumn{2}{|l|}{ Total } & $\begin{array}{r}25 \\
100.0 \% \\
\end{array}$ & $\begin{array}{r}23 \\
100.0 \% \\
\end{array}$ & $\begin{array}{r}48 \\
100.0 \% \\
\end{array}$ \\
\hline \multirow[t]{4}{*}{ Total } & \multirow{3}{*}{$\begin{array}{l}\text { Type of Personal } \\
\text { Engagement That } \\
\text { Would Increase } \\
\text { Trust? }\end{array}$} & $\begin{array}{l}\text { With Others In } \\
\text { Person }\end{array}$ & $\begin{array}{r}38 \\
65.5 \%\end{array}$ & $\begin{array}{r}36 \\
64.3 \%\end{array}$ & $\begin{array}{r}74 \\
64.9 \%\end{array}$ \\
\hline & & With Others Online & $\begin{array}{r}17 \\
29.3 \%\end{array}$ & $\begin{array}{r}10 \\
17.9 \%\end{array}$ & $\begin{array}{r}27 \\
23.7 \%\end{array}$ \\
\hline & & $\begin{array}{l}\text { Prefer Not to } \\
\text { Participate }\end{array}$ & $\begin{array}{r}3 \\
5.2 \%\end{array}$ & $\begin{array}{r}10 \\
17.9 \% \\
\end{array}$ & $\begin{array}{r}13 \\
11.4 \% \\
\end{array}$ \\
\hline & \multicolumn{2}{|l|}{ Total } & $\begin{array}{r}58 \\
100.0 \% \\
\end{array}$ & $\begin{array}{r}56 \\
100.0 \% \\
\end{array}$ & $\begin{array}{r}114 \\
100.0 \% \\
\end{array}$ \\
\hline
\end{tabular}

Table 3

Which Type of Group Involvement Would Increase Your Trust in City Govermet More: Shared Decision-Making Power or Advisory Group That Shares Opinions?

\begin{tabular}{|c|c|c|c|c|c|}
\hline \multirow{2}{*}{ City } & \multirow{4}{*}{$\begin{array}{l} \\
\text { Type of Group } \\
\text { Involvement That } \\
\text { Would Increase } \\
\text { Your Trust More }\end{array}$} & \multirow[b]{3}{*}{$\begin{array}{l}\text { Shared Decision- } \\
\text { Making Power }\end{array}$} & \multicolumn{2}{|c|}{$\begin{array}{l}\text { Do You Have Confidence in } \\
\text { Your City Government? }\end{array}$} & \multirow[b]{2}{*}{ Total } \\
\hline & & & Yes & No & \\
\hline \multirow[t]{4}{*}{ Portland } & & & $\begin{array}{r}23 \\
67.6 \% \\
\end{array}$ & $\begin{array}{r}28 \\
80.0 \% \\
\end{array}$ & $\begin{array}{r}51 \\
73.9 \% \\
\end{array}$ \\
\hline & & Advisory Role & $\begin{array}{r}8 \\
23.5 \% \\
\end{array}$ & $\begin{array}{r}2 \\
5.7 \% \\
\end{array}$ & $\begin{array}{r}10 \\
14.5 \% \\
\end{array}$ \\
\hline & & Neither & $\begin{array}{r}3 \\
8.8 \%\end{array}$ & $\begin{array}{r}5 \\
14.3 \%\end{array}$ & $\begin{array}{r}8 \\
11.6 \%\end{array}$ \\
\hline & Total & & $\begin{array}{r}34 \\
100.0 \%\end{array}$ & $\begin{array}{r}35 \\
100.0 \%\end{array}$ & $\begin{array}{r}69 \\
100.0 \%\end{array}$ \\
\hline \multirow[t]{4}{*}{ Rosario } & \multirow{3}{*}{$\begin{array}{l}\text { Type of Group } \\
\text { Involvement That } \\
\text { Would Increase } \\
\text { Your Trust More }\end{array}$} & $\begin{array}{l}\text { Shared Decision- } \\
\text { Making Power }\end{array}$ & $\begin{array}{r}20 \\
69.0 \% \\
\end{array}$ & $\begin{array}{r}17 \\
73.9 \% \\
\end{array}$ & $\begin{array}{r}37 \\
71.2 \% \\
\end{array}$ \\
\hline & & Advisory Role & $\begin{array}{r}8 \\
27.6 \% \\
\end{array}$ & $\begin{array}{r}4 \\
17.4 \% \\
\end{array}$ & $\begin{array}{r}12 \\
23.1 \% \\
\end{array}$ \\
\hline & & Neither & $\begin{array}{r}1 \\
3.4 \%\end{array}$ & $\begin{array}{r}2 \\
8.7 \%\end{array}$ & $\begin{array}{r}3 \\
5.8 \%\end{array}$ \\
\hline & \multicolumn{2}{|l|}{ Total } & $\begin{array}{r}29 \\
100.0 \%\end{array}$ & $\begin{array}{r}23 \\
100.0 \%\end{array}$ & $\begin{array}{r}52 \\
100.0 \%\end{array}$ \\
\hline \multirow[t]{4}{*}{ Total } & \multirow{3}{*}{$\begin{array}{l}\text { Type of Group } \\
\text { Involvement That } \\
\text { Would Increase } \\
\text { Your Trust More }\end{array}$} & $\begin{array}{l}\text { Shared Decision- } \\
\text { Making Power }\end{array}$ & $\begin{array}{r}43 \\
68.3 \%\end{array}$ & $\begin{array}{r}45 \\
77.6 \%\end{array}$ & $\begin{array}{r}88 \\
72.7 \%\end{array}$ \\
\hline & & Advisory Role & $\begin{array}{r}16 \\
25.4 \% \\
\end{array}$ & $\begin{array}{r}6 \\
10.3 \%\end{array}$ & $\begin{array}{r}22 \\
18.2 \% \\
\end{array}$ \\
\hline & & Neither & $\begin{array}{r}4 \\
6.3 \% \\
\end{array}$ & $\begin{array}{r}7 \\
12.1 \% \\
\end{array}$ & $\begin{array}{r}11 \\
9.1 \%\end{array}$ \\
\hline & \multicolumn{2}{|l|}{ Total } & $\begin{array}{r}63 \\
100.0 \% \\
\end{array}$ & $\begin{array}{r}58 \\
100.0 \% \\
\end{array}$ & $\begin{array}{r}121 \\
100.0 \% \\
\end{array}$ \\
\hline
\end{tabular}


Table 4

What Type of Involvement Would You Be Most Likely To Engage In?

\begin{tabular}{|c|c|c|c|c|c|}
\hline \multirow[b]{2}{*}{ City } & & & \multicolumn{2}{|c|}{$\begin{array}{c}\text { Do You Trust Your City } \\
\text { Government? }\end{array}$} & \multirow[b]{2}{*}{ Total } \\
\hline & & & Yes & No & \\
\hline \multirow[t]{4}{*}{ Portland } & \multirow{3}{*}{$\begin{array}{l}\text { Type of } \\
\text { Engagement Most } \\
\text { Likely to } \\
\text { Participate In }\end{array}$} & In Person & $\begin{array}{r}17 \\
51.5 \% \\
\end{array}$ & $\begin{array}{r}14 \\
41.2 \% \\
\end{array}$ & $\begin{array}{r}31 \\
46.3 \% \\
\end{array}$ \\
\hline & & Online & $\begin{array}{r}13 \\
39.4 \%\end{array}$ & $\begin{array}{r}16 \\
47.1 \% \\
\end{array}$ & $\begin{array}{r}29 \\
43.3 \%\end{array}$ \\
\hline & & $\begin{array}{l}\text { Prefer Not to } \\
\text { Participate }\end{array}$ & $\begin{array}{r}3 \\
9.1 \%\end{array}$ & $\begin{array}{r}4 \\
11.8 \% \\
\end{array}$ & $\begin{array}{r}7 \\
10.4 \%\end{array}$ \\
\hline & \multicolumn{2}{|l|}{ Total } & $\begin{array}{r}33 \\
100.0 \%\end{array}$ & $\begin{array}{r}34 \\
100.0 \%\end{array}$ & $\begin{array}{r}67 \\
100.0 \%\end{array}$ \\
\hline \multirow[t]{4}{*}{ Rosario } & \multirow{3}{*}{$\begin{array}{l}\text { Type of } \\
\text { Engagement Most } \\
\text { Likely to } \\
\text { Participate In }\end{array}$} & In Person & $\begin{array}{r}12 \\
46.2 \% \\
\end{array}$ & $\begin{array}{r}8 \\
34.8 \% \\
\end{array}$ & $\begin{array}{r}20 \\
40.8 \% \\
\end{array}$ \\
\hline & & Online & $\begin{array}{r}12 \\
46.2 \% \\
\end{array}$ & $\begin{array}{r}10 \\
43.5 \% \\
\end{array}$ & $\begin{array}{r}22 \\
44.9 \% \\
\end{array}$ \\
\hline & & $\begin{array}{l}\text { Prefer Not to } \\
\text { Participate }\end{array}$ & $\begin{array}{r}2 \\
7.7 \% \\
\end{array}$ & $\begin{array}{r}5 \\
21.7 \% \\
\end{array}$ & $\begin{array}{r}7 \\
14.3 \% \\
\end{array}$ \\
\hline & \multicolumn{2}{|l|}{ Total } & $\begin{array}{r}26 \\
100.0 \%\end{array}$ & $\begin{array}{r}23 \\
100.0 \%\end{array}$ & $\begin{array}{r}49 \\
100.0 \% \\
\end{array}$ \\
\hline \multirow[t]{4}{*}{ Total } & \multirow{3}{*}{$\begin{array}{l}\text { Type of } \\
\text { Engagement Most } \\
\text { Likely to } \\
\text { Participate In }\end{array}$} & In Person & $\begin{array}{r}29 \\
49.2 \% \\
\end{array}$ & $\begin{array}{r}22 \\
38.6 \% \\
\end{array}$ & $\begin{array}{r}51 \\
44.0 \% \\
\end{array}$ \\
\hline & & Online & $\begin{array}{r}25 \\
42.4 \%\end{array}$ & $\begin{array}{r}26 \\
45.6 \%\end{array}$ & $\begin{array}{r}51 \\
44.0 \%\end{array}$ \\
\hline & & $\begin{array}{l}\text { Prefer Not to } \\
\text { Participate }\end{array}$ & $\begin{array}{r}5 \\
8.5 \% \\
\end{array}$ & $\begin{array}{r}9 \\
15.8 \% \\
\end{array}$ & $\begin{array}{r}14 \\
12.1 \% \\
\end{array}$ \\
\hline & \multicolumn{2}{|l|}{ Total } & $\begin{array}{r}59 \\
100.0 \% \\
\end{array}$ & $\begin{array}{r}57 \\
100.0 \% \\
\end{array}$ & $\begin{array}{r}116 \\
100.0 \% \\
\end{array}$ \\
\hline
\end{tabular}

Table 5

Type of Group Involvement That Would Increase Trust by Existing Confidence and City

\begin{tabular}{|c|c|c|c|c|c|}
\hline \multirow[b]{2}{*}{ City } & \multirow{4}{*}{$\begin{array}{l}\text { Type of Group } \\
\text { Involvement That } \\
\text { Would Increase } \\
\text { Trust }\end{array}$} & & \multicolumn{2}{|c|}{$\begin{array}{l}\text { Do You Have Confidence in } \\
\text { Your City Government? }\end{array}$} & \multirow[b]{2}{*}{ Total } \\
\hline & & & Yes & No & \\
\hline \multirow[t]{4}{*}{ Portland } & & $\begin{array}{l}\text { Shared Decision- } \\
\text { Making Power }\end{array}$ & $\begin{array}{r}23 \\
67.6 \% \\
\end{array}$ & $\begin{array}{r}28 \\
80.0 \% \\
\end{array}$ & $\begin{array}{r}51 \\
73.9 \% \\
\end{array}$ \\
\hline & & $\begin{array}{l}\text { Advisory } \\
\text { Group/Sharing } \\
\text { Opinions }\end{array}$ & $\begin{array}{r}8 \\
23.5 \% \\
\end{array}$ & $\begin{array}{r}2 \\
5.7 \% \\
\end{array}$ & $\begin{array}{r}10 \\
14.5 \% \\
\end{array}$ \\
\hline & & Neither & $\begin{array}{r}3 \\
8.8 \% \\
\end{array}$ & $\begin{array}{r}5 \\
14.3 \% \\
\end{array}$ & $\begin{array}{r}8 \\
11.6 \% \\
\end{array}$ \\
\hline & Total & & $\begin{array}{r}34 \\
100.0 \% \\
\end{array}$ & $\begin{array}{r}35 \\
100.0 \% \\
\end{array}$ & $\begin{array}{r}69 \\
100.0 \% \\
\end{array}$ \\
\hline \multirow[t]{4}{*}{ Rosario } & \multirow{3}{*}{$\begin{array}{l}\text { Type of Group } \\
\text { Involvement That } \\
\text { Would Increase } \\
\text { Trust }\end{array}$} & $\begin{array}{l}\text { Shared Decision- } \\
\text { Making Power }\end{array}$ & $\begin{array}{r}20 \\
69.0 \% \\
\end{array}$ & $\begin{array}{r}17 \\
73.9 \% \\
\end{array}$ & $\begin{array}{r}37 \\
71.2 \% \\
\end{array}$ \\
\hline & & $\begin{array}{l}\text { Advisory } \\
\text { Group/Sharing } \\
\text { Opinions }\end{array}$ & $\begin{array}{r}8 \\
27.6 \%\end{array}$ & $\begin{array}{r}4 \\
17.4 \%\end{array}$ & $\begin{array}{r}12 \\
23.1 \%\end{array}$ \\
\hline & & Neither & $\begin{array}{r}1 \\
3.4 \% \\
\end{array}$ & $\begin{array}{r}2 \\
8.7 \% \\
\end{array}$ & $\begin{array}{r}3 \\
5.8 \% \\
\end{array}$ \\
\hline & \multicolumn{2}{|l|}{ Total } & $\begin{array}{r}29 \\
100.0 \% \\
\end{array}$ & $\begin{array}{r}23 \\
100.0 \% \\
\end{array}$ & $\begin{array}{r}52 \\
100.0 \% \\
\end{array}$ \\
\hline \multirow[t]{4}{*}{ Total } & \multirow{3}{*}{$\begin{array}{l}\text { Type of Group } \\
\text { Involvement That } \\
\text { Would Increase } \\
\text { Trust }\end{array}$} & $\begin{array}{l}\text { Shared Decision- } \\
\text { Making Power }\end{array}$ & $\begin{array}{r}43 \\
68.3 \% \\
\end{array}$ & $\begin{array}{r}45 \\
77.6 \% \\
\end{array}$ & $\begin{array}{r}88 \\
72.7 \% \\
\end{array}$ \\
\hline & & $\begin{array}{l}\text { Advisory } \\
\text { Group/Sharing } \\
\text { Opinions }\end{array}$ & $\begin{array}{r}16 \\
25.4 \% \\
\end{array}$ & $\begin{array}{r}6 \\
10.3 \%\end{array}$ & $\begin{array}{r}22 \\
18.2 \% \\
\end{array}$ \\
\hline & & Neither & $\begin{array}{r}4 \\
6.3 \% \\
\end{array}$ & $\begin{array}{r}7 \\
12.1 \% \\
\end{array}$ & $\begin{array}{r}11 \\
9.1 \% \\
\end{array}$ \\
\hline & Total & & $\begin{array}{r}63 \\
100.0 \% \\
\end{array}$ & $\begin{array}{r}58 \\
100.0 \% \\
\end{array}$ & $\begin{array}{r}121 \\
100.0 \% \\
\end{array}$ \\
\hline
\end{tabular}


Table 6

Which Type of Group Involvement Would Increase Your Trust in City Govermet More: Shared Decision-Making Power or Advisory Group That Shares Opinions?

\begin{tabular}{|c|c|c|c|c|c|}
\hline \multirow[b]{2}{*}{ City } & & & \multicolumn{2}{|c|}{$\begin{array}{l}\text { Do You Have Confidence in } \\
\text { Your City Government? }\end{array}$} & \multirow[b]{2}{*}{ Total } \\
\hline & & & Yes & No & \\
\hline \multirow[t]{5}{*}{ Portland } & \multirow{4}{*}{$\begin{array}{l}\text { Type of Group } \\
\text { Involvement That } \\
\text { Would Increase } \\
\text { Your Trust More }\end{array}$} & Shared Decision- & 23 & 28 & 51 \\
\hline & & Making Power & $67.6 \%$ & $80.0 \%$ & $73.9 \%$ \\
\hline & & Advisory Role & $\begin{array}{r}8 \\
23.5 \%\end{array}$ & $\begin{array}{r}2 \\
5.7 \%\end{array}$ & $\begin{array}{r}10 \\
14.5 \%\end{array}$ \\
\hline & & Neither & $\begin{array}{r}3 \\
8.8 \% \\
\end{array}$ & $\begin{array}{r}5 \\
14.3 \% \\
\end{array}$ & $\begin{array}{r}8 \\
11.6 \% \\
\end{array}$ \\
\hline & \multicolumn{2}{|l|}{ Total } & $\begin{array}{r}34 \\
100.0 \% \\
\end{array}$ & $\begin{array}{r}35 \\
100.0 \%\end{array}$ & $\begin{array}{r}69 \\
100.0 \%\end{array}$ \\
\hline \multirow[t]{4}{*}{ Rosario } & \multirow{3}{*}{$\begin{array}{l}\text { Type of Group } \\
\text { Involvement That } \\
\text { Would Increase } \\
\text { Your Trust More }\end{array}$} & $\begin{array}{l}\text { Shared Decision- } \\
\text { Making Power }\end{array}$ & $\begin{array}{r}20 \\
69.0 \% \\
\end{array}$ & $\begin{array}{r}17 \\
73.9 \% \\
\end{array}$ & $\begin{array}{r}37 \\
71.2 \% \\
\end{array}$ \\
\hline & & Advisory Role & $\begin{array}{r}8 \\
27.6 \%\end{array}$ & $\begin{array}{r}4 \\
17.4 \%\end{array}$ & $\begin{array}{r}12 \\
23.1 \%\end{array}$ \\
\hline & & Neither & $\begin{array}{r}1 \\
3.4 \% \\
\end{array}$ & $\begin{array}{r}2 \\
8.7 \% \\
\end{array}$ & $\begin{array}{r}3 \\
5.8 \% \\
\end{array}$ \\
\hline & \multicolumn{2}{|l|}{ Total } & $\begin{array}{r}29 \\
100.0 \% \\
\end{array}$ & $\begin{array}{r}23 \\
100.0 \% \\
\end{array}$ & $\begin{array}{r}52 \\
100.0 \% \\
\end{array}$ \\
\hline \multirow[t]{4}{*}{ Total } & \multirow{3}{*}{$\begin{array}{l}\text { Type of Group } \\
\text { Involvement That } \\
\text { Would Increase } \\
\text { Your Trust More }\end{array}$} & $\begin{array}{l}\text { Shared Decision- } \\
\text { Making Power }\end{array}$ & $\begin{array}{r}43 \\
68.3 \% \\
\end{array}$ & $\begin{array}{r}45 \\
77.6 \% \\
\end{array}$ & $\begin{array}{r}88 \\
72.7 \% \\
\end{array}$ \\
\hline & & Advisory Role & $\begin{array}{r}16 \\
25.4 \% \\
\end{array}$ & $\begin{array}{r}6 \\
10.3 \% \\
\end{array}$ & $\begin{array}{r}22 \\
18.2 \% \\
\end{array}$ \\
\hline & & Neither & $\begin{array}{r}4 \\
6.3 \% \\
\end{array}$ & $\begin{array}{r}7 \\
12.1 \% \\
\end{array}$ & $\begin{array}{r}11 \\
9.1 \% \\
\end{array}$ \\
\hline & \multicolumn{2}{|l|}{ Total } & $\begin{array}{r}63 \\
100.0 \% \\
\end{array}$ & $\begin{array}{r}58 \\
100.0 \% \\
\end{array}$ & $\begin{array}{r}121 \\
100.0 \% \\
\end{array}$ \\
\hline
\end{tabular}

Table 7

Type of Group Involvement That Would Increase Trust by Existing Confidence and Income Level

\begin{tabular}{|c|c|c|c|c|c|}
\hline \multirow{2}{*}{\multicolumn{3}{|c|}{ Income Quartile Combined }} & \multicolumn{2}{|c|}{$\begin{array}{l}\text { Do You Have Confidence in } \\
\text { Your City Government? }\end{array}$} & \multirow{3}{*}{$\begin{array}{r}\text { Total } \\
41 \\
73.2 \%\end{array}$} \\
\hline & & & \multirow{2}{*}{$\begin{aligned} \text { Yes } \\
17 \\
68.0 \%\end{aligned}$} & \multirow{2}{*}{$\begin{aligned} \text { No } \\
24 \\
77.4 \%\end{aligned}$} & \\
\hline \multirow[t]{5}{*}{ Low Income } & \multirow{4}{*}{$\begin{array}{l}\text { Type of Group } \\
\text { Involvement that } \\
\text { Would Increase } \\
\text { Trust? }\end{array}$} & $\begin{array}{l}\text { Shared Decision- } \\
\text { Making Power }\end{array}$ & & & \\
\hline & & $\begin{array}{l}\text { Advisory } \\
\text { Group/Share }\end{array}$ & 7 & 3 & 10 \\
\hline & & Opinion & $28.0 \%$ & $9.7 \%$ & $17.9 \%$ \\
\hline & & Neither & $\begin{array}{r}1 \\
4.0 \% \\
\end{array}$ & $\begin{array}{r}4 \\
12.9 \% \\
\end{array}$ & $\begin{array}{r}5 \\
8.9 \%\end{array}$ \\
\hline & \multicolumn{2}{|l|}{ Total } & $\begin{array}{r}25 \\
100.0 \%\end{array}$ & $\begin{array}{r}31 \\
100.0 \%\end{array}$ & $\begin{array}{r}56 \\
100.0 \%\end{array}$ \\
\hline \multirow[t]{4}{*}{ Low-Mid Income } & \multirow{3}{*}{$\begin{array}{l}\text { Type of Group } \\
\text { Involvement that } \\
\text { Would Increase } \\
\text { Trust? }\end{array}$} & $\begin{array}{l}\text { Shared Decision- } \\
\text { Making Power }\end{array}$ & $\begin{array}{r}4 \\
80.0 \% \\
\end{array}$ & $\begin{array}{r}7 \\
87.5 \% \\
\end{array}$ & $\begin{array}{r}11 \\
84.6 \% \\
\end{array}$ \\
\hline & & $\begin{array}{l}\text { Advisory } \\
\text { Group/Share }\end{array}$ & 1 & 1 & 2 \\
\hline & & Opinion & $20.0 \%$ & $12.5 \%$ & $15.4 \%$ \\
\hline & \multicolumn{2}{|l|}{ Total } & $\begin{array}{r}5 \\
100.0 \% \\
\end{array}$ & $\begin{array}{r}8 \\
100.0 \% \\
\end{array}$ & $\begin{array}{r}13 \\
100.0 \% \\
\end{array}$ \\
\hline \multirow[t]{5}{*}{$\begin{array}{l}\text { Mid to High-Mid } \\
\text { Income }\end{array}$} & \multirow{4}{*}{$\begin{array}{l}\text { Type of Group } \\
\text { Involvement that } \\
\text { Would Increase } \\
\text { Trust? }\end{array}$} & $\begin{array}{l}\text { Shared Decision- } \\
\text { Making Power }\end{array}$ & $\begin{array}{r}16 \\
76.2 \% \\
\end{array}$ & $\begin{array}{r}7 \\
87.5 \% \\
\end{array}$ & $\begin{array}{r}23 \\
79.3 \%\end{array}$ \\
\hline & & Advisory & 4 & 1 & 5 \\
\hline & & Opinion & $19.0 \%$ & $12.5 \%$ & $17.2 \%$ \\
\hline & & Neither & $\begin{array}{r}1 \\
4.8 \% \\
\end{array}$ & $\begin{array}{r}0 \\
0.0 \% \\
\end{array}$ & $\begin{array}{r}1 \\
3.4 \% \\
\end{array}$ \\
\hline & \multicolumn{2}{|l|}{ Total } & $\begin{array}{r}21 \\
100.0 \% \\
\end{array}$ & $\begin{array}{r}88 \\
100.0 \% \\
\end{array}$ & $\begin{array}{r}29 \\
100.0 \% \\
\end{array}$ \\
\hline \multirow[t]{3}{*}{ High Income } & \multirow{2}{*}{$\begin{array}{l}\text { Type of Group } \\
\text { Involvement that } \\
\text { Would Increase } \\
\text { Trust? }\end{array}$} & \multirow{2}{*}{$\begin{array}{l}\text { Advisory } \\
\text { Group/Share } \\
\text { Opinion }\end{array}$} & 2 & 1 & 3 \\
\hline & & & $100.0 \%$ & $100.0 \%$ & $100.0 \%$ \\
\hline & \multicolumn{2}{|l|}{ Total } & $\begin{array}{r}2 \\
100.0 \% \\
\end{array}$ & $\begin{array}{r}1 \\
100.0 \% \\
\end{array}$ & $\begin{array}{r}3 \\
100.0 \% \\
\end{array}$ \\
\hline \multirow[t]{5}{*}{ Total } & \multirow{4}{*}{$\begin{array}{l}\text { Type of Group } \\
\text { Involvement that } \\
\text { Would Increase } \\
\text { Trust? }\end{array}$} & $\begin{array}{l}\text { Shared Decision- } \\
\text { Making Power }\end{array}$ & $\begin{array}{r}37 \\
69.8 \% \\
\end{array}$ & $\begin{array}{r}38 \\
79.2 \% \\
\end{array}$ & $\begin{array}{r}75 \\
74.3 \% \\
\end{array}$ \\
\hline & & $\begin{array}{l}\text { Advisory } \\
\text { Group/Share }\end{array}$ & 14 & 6 & 20 \\
\hline & & Opinion & $26.4 \%$ & $12.5 \%$ & $19.8 \%$ \\
\hline & & Neither & $\begin{array}{r}2 \\
3.8 \% \\
\end{array}$ & $\begin{array}{r}4 \\
8.3 \% \\
\end{array}$ & $\begin{array}{r}6 \\
5.9 \% \\
\end{array}$ \\
\hline & \multicolumn{2}{|l|}{ Total } & $\begin{array}{r}53 \\
100.0 \% \\
\end{array}$ & $\begin{array}{r}48 \\
100.0 \% \\
\end{array}$ & $\begin{array}{r}101 \\
100.0 \% \\
\end{array}$ \\
\hline
\end{tabular}


Table 8

Type of Group Involvement That Would Increase Trust by Existing Confidence and Gender

\begin{tabular}{|c|c|c|c|c|c|}
\hline \multirow[b]{2}{*}{ Sex/Gender } & & & \multicolumn{2}{|c|}{$\begin{array}{l}\text { Do You Have Confidence in } \\
\text { Your City Government? }\end{array}$} & \multirow[b]{2}{*}{ Total } \\
\hline & & & Yes & No & \\
\hline \multirow[t]{5}{*}{ Female } & \multirow{4}{*}{$\begin{array}{l}\text { Type of } \\
\text { Involvement That } \\
\text { Would Increase } \\
\text { Trust }\end{array}$} & $\begin{array}{l}\text { Shared Decision- } \\
\text { Making Power }\end{array}$ & $\begin{array}{r}24 \\
63.2 \% \\
\end{array}$ & $\begin{array}{r}22 \\
84.6 \% \\
\end{array}$ & $\begin{array}{r}46 \\
71.9 \% \\
\end{array}$ \\
\hline & & $\begin{array}{l}\text { Advisory } \\
\text { Group/Share }\end{array}$ & 11 & 2 & 13 \\
\hline & & Opinions & $28.9 \%$ & $7.7 \%$ & $20.3 \%$ \\
\hline & & Neither & $\begin{array}{r}3 \\
7.9 \% \\
\end{array}$ & $\begin{array}{r}2 \\
7.7 \% \\
\end{array}$ & $\begin{array}{r}5 \\
7.8 \% \\
\end{array}$ \\
\hline & \multicolumn{2}{|l|}{ Total } & $\begin{array}{r}38 \\
100.0 \% \\
\end{array}$ & $\begin{array}{r}26 \\
100.0 \% \\
\end{array}$ & $\begin{array}{r}64 \\
100.0 \% \\
\end{array}$ \\
\hline \multirow[t]{4}{*}{ Male } & \multirow{3}{*}{$\begin{array}{l}\text { Type of } \\
\text { Involvement That } \\
\text { Would Increase } \\
\text { Trust }\end{array}$} & $\begin{array}{l}\text { Shared Decision- } \\
\text { Making Power }\end{array}$ & $\begin{array}{r}14 \\
77.8 \% \\
\end{array}$ & $\begin{array}{r}15 \\
65.2 \% \\
\end{array}$ & $\begin{array}{r}29 \\
70.7 \% \\
\end{array}$ \\
\hline & & $\begin{array}{l}\text { Advisory } \\
\text { Group/Share } \\
\text { Opinions }\end{array}$ & $\begin{array}{r}4 \\
22.2 \%\end{array}$ & $\begin{array}{r}4 \\
17.4 \%\end{array}$ & $\begin{array}{r}8 \\
19.5 \%\end{array}$ \\
\hline & & Neither & $\begin{array}{r}0 \\
0.0 \% \\
\end{array}$ & $\begin{array}{r}4 \\
17.4 \% \\
\end{array}$ & $\begin{array}{r}4 \\
9.8 \% \\
\end{array}$ \\
\hline & \multicolumn{2}{|l|}{ Total } & $\begin{array}{r}18 \\
100.0 \% \\
\end{array}$ & $\begin{array}{r}23 \\
100.0 \% \\
\end{array}$ & $\begin{array}{r}41 \\
100.0 \% \\
\end{array}$ \\
\hline \multirow[t]{3}{*}{ non-binary } & \multirow{2}{*}{$\begin{array}{l}\text { Type of } \\
\text { Involvement That } \\
\text { Would Increase } \\
\text { Trust } \\
\end{array}$} & \multirow[t]{2}{*}{$\begin{array}{l}\text { Shared Decision- } \\
\text { Making Power }\end{array}$} & 1 & 3 & 4 \\
\hline & & & $100.0 \%$ & $100.0 \%$ & $100.0 \%$ \\
\hline & Total & & $\begin{array}{r}1 \\
100.0 \% \\
\end{array}$ & $\begin{array}{r}3 \\
100.0 \% \\
\end{array}$ & $\begin{array}{r}4 \\
100.0 \% \\
\end{array}$ \\
\hline \multirow[t]{3}{*}{ Other } & \multirow{2}{*}{$\begin{array}{l}\text { Type of } \\
\text { Involvement That } \\
\text { Would Increase } \\
\text { Trust }\end{array}$} & \multirow[t]{2}{*}{$\begin{array}{l}\text { Shared Decision- } \\
\text { Making Power }\end{array}$} & 1 & 1 & 2 \\
\hline & & & $100.0 \%$ & $100.0 \%$ & $100.0 \%$ \\
\hline & \multicolumn{2}{|l|}{ Total } & $\begin{array}{r}1 \\
100.0 \% \\
\end{array}$ & $\begin{array}{r}1 \\
100.0 \% \\
\end{array}$ & $\begin{array}{r}2 \\
100.0 \% \\
\end{array}$ \\
\hline \multirow[t]{5}{*}{ Total } & \multirow{4}{*}{$\begin{array}{l}\text { Type of } \\
\text { Involvement That } \\
\text { Would Increase } \\
\text { Trust }\end{array}$} & $\begin{array}{l}\text { Shared Decision- } \\
\text { Making Power }\end{array}$ & $\begin{array}{r}40 \\
69.0 \%\end{array}$ & $\begin{array}{r}41 \\
77.4 \% \\
\end{array}$ & $\begin{array}{r}81 \\
73.0 \% \\
\end{array}$ \\
\hline & & $\begin{array}{l}\text { Advisory } \\
\text { Group/Share }\end{array}$ & 15 & 6 & 21 \\
\hline & & Opinions & $25.9 \%$ & $11.3 \%$ & $18.9 \%$ \\
\hline & & Neither & $\begin{array}{r}3 \\
5.2 \% \\
\end{array}$ & $\begin{array}{r}6 \\
11.3 \% \\
\end{array}$ & $\begin{array}{r}9 \\
8.1 \%\end{array}$ \\
\hline & \multicolumn{2}{|l|}{ Total } & $\begin{array}{r}58 \\
100.0 \% \\
\end{array}$ & $\begin{array}{r}53 \\
100.0 \% \\
\end{array}$ & $\begin{array}{r}111 \\
100.0 \% \\
\end{array}$ \\
\hline
\end{tabular}




\section{REFERENCES}

Abbott, Carl. Portland: Planning, Politics and Growth in a Twentieth-Century City. Lincoln, NB: University of Nebraska Press, 1983.

Abeyasinghe, Ranmali. 2004. Democracy, political stability, and developing country growth: Theory and evidence. Honors Project: Illinois Wesleyan University.

Almansi, Florencia. 2009. Rosario's development; interview with Miguel Lfischitz, mayor of Rosario, Argentina. Environment \& Urbanization. International Institute for Environment and Development. Vol 21(1): 19-35.

Attree, P., French, B., Milton, B., Povall, S., Whitehead, M., \& Popay, J. 2011. The experience of community engagement for individuals: A rapid review of evidence. Health \& Social Care in the Community, 19(3), 250-260.

Ashforth, B. E., \& Gibbs, B. W. 1990. "The Double Edge of Organizational Legitimation." Organization Science. 1: 177-194.

Attree, Pamela, Beverley French, Beth Milton, Susan Povall, Margaret Whitehead, and Jennie Popay. 2011. "The Experience Of Community Engagement For Individuals: A Rapid Review Of Evidence." Health \& Social Care In The Community, 19 (3): 250-260.

Barber, Benjamin R. 1984. Strong Democracy: Participatory Politics for a New Age. 1st ed. Berkeley, Calif: University of California.

Beane, J., Turner, J., Jones, D., \& Lipka, R. 1981. Long-term effects of community-service programs. Curriculum Inquiry, 11(2), 143-155.

Beebe, Craig. "Portland region nears 2.4 million residents, growing by 41,000 last year." Oregon Metro. http://www.oregonmetro.gov/news/portland-region-nears-24-million-residentsgrowing-41000-last-year (accessed 14 Apr 2017).

Beetham, D. 1991. The Legitimization of Power. Basingstoke: Macmillan.

Beetham, D., and C. Lord. 1998. Legitimacy and the EU. London: Longman.

Bernstein, Steven, and William D. Coleman. 2009. Unsettled Legitimacy: Political Community, Power, and Authority in a Global Era. Vancouver: UBC Press.

Berry, Jeffrey M., Kent E. Portney, and Ken Thomson. The Rebirth of Urban Democracy. Washington, D.C.: The Brookings Institution, 1993. 
Bevir, M. 2012. Governance: A Very Short Introduction. Oxford: Oxford University Press.

Bohn, S. 2012. Corruption in Latin America: Understanding the Perception-Exposure Gap. Journal Of Politics In Latin America, 4(3), 67-95.

Campbell, Tim, and Harald Fuhr. 2004. Leadership And Innovation In Subnational Government. 1 st ed. Washington, D.C.: The World Bank.

Cassie, Caitlin. (2010). "Portland, Oregon: Not so hip after all." Public Policy \& Governance Review. Vol. 1 (2), 1-22.

"City Government Structure." City of Portland. https://www.portlandoregon.gov/auditor/article/ 9178 (accessed 14 Apr 2017).

Clucas, Richard A. 2006. Readings \& Cases In State And Local Politics. Boston: Houghton Mifflin.

Clucas, Richard A, and Melody Ellis Valdini. 2014. The Character Of Democracy: How Institutions Shape Politics. New York City: Oxford University Press.

Copeland, Donna. "Understanding Legitimacy and its Application to Citizen Participation Policy Decisions." Master's thesis, Evergreen State College, 1991.

Deephouse, D.L. \& Suchman, M. (2008) Legitimacy in Organizational Institutionalism. The Sage Handbook of Organizational Institutionalism. Eds. Royston G, Oliver, C, Sahlin, K. and Suddaby, R. SAGE Publications. (2008) London. pp.49-54.

Digby-Junger, Richard. "White Flight." St. James Encyclopedia of Popular Culture, edited by Sara Pendergast and Tom Pendergast, vol. 5, St. James Press, 2000, pp. 128-129. U.S. History in Context, link.galegroup.com/apps/doc/CX3409002659/UHIC? $\mathrm{u}=\mathrm{sand} 55832 \& \mathrm{xid}=\mathrm{f} 73 \mathrm{e} 6 \mathrm{be} 9$. Accessed 2 May 2017.

Ehrlich, Thomas. 2000. Civic Responsibility And Higher Education. Phoenix, AZ: Oryx Press.

Elster, Jon. 1982. "Marxism, Functionalism, And Game Theory: The Case for Methodological Individualism." Theory And Society, 11 (4): 453-482.

Fay, Brian. 1985. "Theory and metatheory in social science? Or, why the philosophy of social science is so hard." Metaphilosophy, 16 (2-3):150-165.

George, Victor, and Paul Wilding. 1984. The Impact of Social Policy. London: Routledge. 
Gilley, Bruce. 2006. "The Determinants of State Legitimacy: Results for 72 Countries." International Political Science Review 27 (1): 47-71.

Gilman, Hollie Russon. 2016. Participatory Budgeting And Civic Tech: The Revival Of Citizen Engagement. Washington D.C.: Georgetown University Press.

Grafstein, R.. 1981. "The Failure of Weber's Conception of Legitimacy: Its Causes and Implications." The Journal of Politics, 43(2), 456-472.

Hedge, David. 1998. Governance And The Changing American States. Boulder: Westview Press.

Hollis, M. (2002) Philosophy of Social Science, in The Blackwell Companion to Philosophy, Second Edition (eds N. Bunnin and E. P. Tsui-James), Blackwell Publishing Ltd, Oxford, UK.

Ives, Andrew. 2015. "Neoliberalism And The Concept Of Governance: Renewing With An Older Liberal Tradition To Legitimate The Power Of Capital." Mémoire(s), Identité(s), Marginalité(s) Dans Le Monde Occidental Contemporain. Cahiers du MIMMOC (14).

Jennings, M. K. 2002. Generation units and the student protest movement in the United States: An intra- and intergenerational analysis. Political Psychology, 23(2), 303-324.

Johnson, C. 2015. "Local Civic Participation and Democratic Legitimacy: Evidence from England and Wales.” Political Studies. (63): 765-792.

Jorge, José Eduardo. 2009. “Cultura política y democracia in Argentina.” Editorial de la Universidad de La Plata.

Karush, Matthew B. 2002. Workers or Citizens: Democracy and identity in Rosario, Argentina (1912-1930). Albuquerque: University of New Mexico Press.

Kim, Pan Suk, John Halligan, Namshin Cho, Cheol H. Oh, and Angela M. Eikenberry. 2005.

"Toward Participatory And Transparent Governance: Report On The Sixth Global Forum On Reinventing Government." Public Administration Review, 65 (6): 646-654.

Leistner, Paul R. "The Dynamics of Creating Strong Democracy in Portland, OR - 1974 to 2013.” Doctoral Dissertation, Portland State University, 2013.

Little, Daniel. 1991. Varieties of Social Explanation: An Introduction to the Philosophy of Social Science. Boulder, Colorado: Westview Press. 
Lind, Michael. 2011. "How Reaganism Actually Started With Carter." Salon.com. Retrieved from http://www.salon.com/2011/02/08/lind_reaganism_carter/.

Mahoney, J. L., \& Stattin, H. 2000. Leisure acticities and adolescent antisocial behavior: The role of structure and social context. Journal of Adolescence, 23(2), 113-127.

Mander, Benedict. 2016. "Argentina: Home to the majority of Latin America's tech unicorns." Financial Times. Retrieved from https://www.ft.com/content/687f5a58-5807-11e6-9f70badea1b336d4.

McAdam, D. 1988. Freedom summer. New York: Oxford University Press.

McAdam, D. 1989. The biographical consequences of activism. American Sociological Review, 54(5), 744-760.

McMahon, Christopher. 2012. Public Capitalism: The Political Authority Of Corporate Executives. Philadelphia: University of Pennsylvania Press.

Musomer. [PowerPoint Presentation] Retrieved from Online Lecture Notes Website http:// home.ku.edu.tr/ musomer/Lecture\%20Notes/int1204\%20State-authority.pdf

Pancer, S. Mark. 2014. The Psychology Of Citizenship And Civic Engagement. New York: Oxford University Press.

Pein, Corey. "Oregonians Are Reporting More Hate and Bias Crimes than Anyone in the U.S." 23 March 2017. http://www.wweek.com/news/2017/03/23/oregonians-are-reportingmore-hate-and-bias-crimes-than-anyone-in-u-s/ (accessed 23 March 2017).

Pérez-Liñan, A. 2002. Argentina and the New Pattern of Political Instability in Latin America. Department of Political Science, University of Pittsburgh.

Perlroth, Nicole. 2015. "In a Global Market for Hacking Talent, Argentines Stand Out." The New York Times. Retrieved from: https://www.nytimes.com/2015/12/01/technology/in-aglobal-market-for-hacking-talent-argentines-stand-out.html?_r=0.

Peters, B. Guy. 2001. The Future Of Governing. 2nd ed. Lawrence: University Press of Kansas.

Petras, J. 1989. Class Politics, State Power and Legitimacy. Economic and Political Weekly, 24(34), 1955-1958.

Public Trust in Government Remains Near Historic Lows as Partisan Attitudes Shift. 3 May 2017. Pew Research Center: U.S. Politics \& Policy. Accessed 9 May 2017. 
Putnam, Robert D. Winter 1996. “The Strange Disappearance of Civic America.” The American Prospect. 7 (24): 34-48.

Putnam, Robert D. and Lewis M. Feldstein, with Don Cohen. Better Together: Restoring the American Community. New York: Simon \& Schuster, 2003.

Rebuilding Effective Government. 2002.1st ed. Bratislava, Slovakia: United Nations Development Programme.

Reid, William A. 1925. Rosario: Argentina's Second City. Washington D.C.: Pan American Union.

Reilly, Charles A. 1995. New Paths To Democratic Development In Latin America. Boulder: Rienner.

Roos, K., and Lidström, A. 2014. "Local Policies and Local Government Legitimacy. The Swedish Case." Urban Research \& Practice. 7 (2): 137-152.

Santana, A. 2012. "Three Elements of Stakeholder Legitimacy.” Journal of Business Ethics. 105 (2): 257-265.

Saunier, Pierre-Yves and Shane Ewen. 2008. Another Global City: Historical Explorations into the Transnational Municipal Moment, 1850-2000. New York: Palgrave Macmillan.

Skocpol, T. 1997. "The Tocqueville problem: Civic engagement in American democracy." Social Science History. 21 (4): 455-479.

Swaner, Rachel. 2017. Trust Matters: Enhancing Government Legitimacy through Participatory Budgeting. New Political Science. 39:1, 95-108.

Taylor, T. P., \& Pancer, S. M. (2007). Community service experiences and commitment to volunteering. Journal of Applied Social Psychology, 37(2) 320-345.

The AmericasBarometer by the Latin American Public Opinion Project (LAPOP), www.LapopSurveys.org.

The Tragedy of Argentina: A Century of Decline. 17 Feb 2014. The Economist. Accessed on 4 Mar 2017. 
Tieu, T. T., Pancer, S. M., Pratt, M. W., Wintre, M. G., Birnie-Lefcovitch, S., Polivy, J., \& Adams, G. 2010. Helping out or hanging out: the features of involvementt and how it relates to university adjustment. Higher Education, 60(3), 343-355.

Urban and Peri-urban Agriculture in Latin America. Food and Agriculture Organization of the United Nations. Retrieved from http://www.fao.org/ag/agp/greenercities/en/GGCLAC/ rosario.html. Accessed on 24 Nov 2015.

Vanden, H. \& Prevost, G. 2014. Politics of Latin America: The power game (5th ed.). Oxford: Oxford University Press.

Warkentin, M., Gefen, D., Pavlov, P. and Rose, G.: Encouraging Citizen Adoption, of eGovernment by Building Trust, Electronic Markets, Vol. 12(3) (2002) pp. 157-162.

Weber, M. 1947. The Theory of Social and Economic Organization. New York: Free Press.

World Values Survey: Findings and insights. (2014) World Values Survey Database. Retrieved from: http://www.worldvaluessurvey.org/WVSContents.jsp. Accessed 10 Oct 2015.

World Values Survey, Wave 6: 2010-2014, V202K. (2014) World Values Survey Database. Retrieved from: http://www.worldvaluessurvey.org/WVSOnline.jsp. Accessed 10 Oct 2015.

World Values Survey, Wave 6: 2010-2014, V264K. (2014) World Values Survey Database. Retrieved from: http://www.worldvaluessurvey.org/WVSOnline.jsp. Accessed 10 Oct 2015.

World Values Survey, Wave 6: 2010-2014, V228G. (2014) World Values Survey Database. Retrieved from: http://www.worldvaluessurvey.org/WVSOnline.jsp. Accessed 10 Oct 2015.

World Values Survey, Wave 6: 2010-2014, V228J. (2014) World Values Survey Database. Retrieved from: http://www.worldvaluessurvey.org/WVSOnline.jsp. Accessed 10 Oct 2015.

World Values Survey, Wave 6: 2010-2014, V228K. (2014) World Values Survey Database. Retrieved from: http://www.worldvaluessurvey.org/WVSOnline.jsp. Accessed 10 Oct 2015. 